\title{
Fruits Morphological Qualitative Traits, Biochemical Components and Pungency Strength of Spicy Pepper from Maleh Valley in Morocco
}

\author{
N. Benbrahim ${ }^{1, *}$, R. Mentag ${ }^{1}$, Youssef Elghzaoui' ${ }^{2}$ Zine Abidine Triqui ${ }^{2}$, Said Gmouh ${ }^{3}$, \\ Noreddine ES-Safi ${ }^{4}$, Jamila Halim ${ }^{4}$, F. Gaboun ${ }^{1}$, Mona Taghouti ${ }^{1}$ \\ ${ }^{1}$ National Institute for Agricultural Research (INRA), BP 6356- Institutes 1010, Morocco \\ ${ }^{2}$ Department of Biology, Faculty of Sciences, Mohammed-V University, Morocco \\ ${ }^{3}$ Department of Chemistry, Ben M'Sik Faculty of Sciences, Hassan-II University of Mohammedia-Casablanca, Morocco \\ ${ }^{4}$ Mohammed-V University, Morocco
}

Received June 16, 2019; Revised September 26, 2019; Accepted October 7, 2019

Copyright $\odot 2019$ by authors, all rights reserved. Authors agree that this article remains permanently open access under the terms of the Creative Commons Attribution License 4.0 International License

\begin{abstract}
Phenotypic diversity, biochemical components and pungency strength were assessed for eighteen spicy pepper accessions from Maleh valley in Morocco. Six plant samples were randomly collected in farmers' field across three target localities during 2015 growing season. Eight fruits from each sampled plant were characterized using eight phenotypic qualitative traits and biochemical components. Results revealed a wider genetic variability within accessions (52\%) than among accessions (43\%) and among sites $(5 \%)$, leading to a substantial genetic differentiation among accessions (PhiPR $=0.453^{* * *}$ ) and within accessions (PhiPT $=0.477^{* * *}$ ) and a strong seed exchange network. The greater part of trait frequency was accounted for fruit shape (SWI=0.132), texture of fruit surface $(\mathrm{SWI}=0.270)$, fruit attitude $(\mathrm{SWI}=0.260)$, pericarp sinuation $(\mathrm{SWI}=0.119)$ and for fruit color $(\mathrm{SWI}=0.246)$ and brightness (SWI =0.218). Biochemical components analysis revealed that spicy fruits of Maleh valley are identified as having high nutritional value; carbohydrates (53.2mg/g FW), total phenolic compounds (73.3mgGAE/100g), and total lipids $(1.27 \mathrm{mg} / \mathrm{g} \mathrm{DM})$ were composed mainly of unsaturated fatty acid (87\%) and a high ratio of $\omega_{6} / \omega_{3}$ (5.6). Furthermore, Capsaicinoids concentration $(2.16 \mathrm{mg} / \mathrm{gDM})$ varied among accessions from 1.67 to 2.82 while the ratio of capsaicin/dihydrocapsaicin (1.83) was similar in all accessions. Fruit spicy was categorized into highly pungent group (27550.5 - $44780.7 \mathrm{SHU}$ ) according to Scoville organoleptic test.
\end{abstract}

Keywords Spicy Pepper, Phenotypic Characters, Biochemical Composition, Pungency, Morocco

\section{Introduction}

Pepper is an important crop since their fruits are widely consumed in the world (FAO, 2010) and provide a major source of antioxidant compounds (Antonious et al, (2006), Deepa et al, (2007)). Pepper is increasingly recognized as an excellent health benefit according to secondary metabolites contains such as vitamins, carotenoïds, flavonoïds and capsaicinoïds (Howard and Wildman (2007); Deepa et al, (2007); Topuz and Ozdemir, (2007); Araceli et al, (2011); Tundis et al, (2012); Chavèz-Mendoza et al, (2013) and Wahyuni et al, (2013)). Those metabolites are involved in determining fruits color, aroma and taste (Ha et al, (2007); Gangadhar et al, (2012); Zaki et al, (2013) and Ranjith et al, (2015)) and are synthesized in protecting plants against biotic (Schultze and Spiteller, 2009) and abiotic stresses (Zewdi and Bodland (2000); Munns, (2002) and Munns, (2008)). The amount and composition of these metabolites vary among genotypes (Gougoulias et al, (2017); Antonious et al, (2006)), and are affected by environment (Zewdie and Bosland, 2000), agronomic practices (Guinoza et al, 2015) and by fruit maturity (Buczkowska et al, 2013). Fruit red color is a consequence of Capsanthin, capsorubin and cryptoxanthin pigments accumulation in the pericarp (Ha et al, 2007). Capsanthin is the major carotenoid of red pepper (Matsufuji et al, (1998); Ha et al, (2007)), while fruit spicy taste is conferred by Capsaicinoids (Dong, (2000); Manirakiza et al, (2003)). Capsaicin and dihydrocapsaicin are the primary components of the Capsaicinoids as they account together for $80-90 \%$ of pungency (Laskaridou-Monnerville, (1999); Garcès-claver et al, (2006)). Pungency is a distinctive fruits characteristic of Capsicum genus (Manirakiza et al, 2003). Pungency 
strength is measured by Scoville Heat Units (SHU) using Scoville organoleptic test (Scoville, 1912). Five levels of pungency are defined based on the use of Scoville heat units (SHU) as non-pungent (0-700 SHU), mildly pungent (700-3000 SHU), moderately pungent (3000-25000 SHU), highly pungent (25000-70000 SHU) and very highly pungent (>80000 SHU) (Weiss et al., 2002). The Capsaicinoids health-promoting benefit properties make pungency strength a major criterion of pepper fruit quality (Jarret et al., 2007). Indeed, previous studies underline their antioxidant potential (Alvarez-Parrilla et al, (2011), Chávez-Mendoza et al, (2013), Nadeem et al, (2011); Tundis et al, (2012); Gougoulia et al, (2017); Rodica et al, (2017)), antimicrobial activity (Kappel et al., 2008), anti-inflammatory proprieties (Zimmer et al, 2012) and anti-proliferative effects (Middleton et al., (2000); Mori et al, (2006)). There might be involved therefore in protecting human health through preventing the widespread human diseases as cancer (Djamgoz and Isbilen, (2006), Aggarwal et al, (2006); Aggarwal et al, (2009) and Jeong et al, (2011)). Synthesis of capsaicinoids may operate as general defense mechanism against various stresses (Zewdie and Bosland, (2000); Zhu, (2002); Munns et al, (2008) and Schulze et al. (2009)). Salty environment stress is among a major abiotic stress that globally affects $20 \%$ of total irrigated lands (Munns and Tester, 2008). Salinity affects negatively plant growth and productivity through osmotic stress (Munns et al, (2008)) and/or oxidative stress (Zhu, 2002). Accordingly, the low water availability in salty substrate increases phenylalanine ammonialyase (PAL), cinnamic acid 4-hydroxylase $(\mathrm{C} 4 \mathrm{H})$ and capsaicin synthase (CS) activity. All of those enzymes are involved in capsaicin biosynthesis (Munns et al, (2002); Munns et al, (2008)). Thus, capsaicin biosynthesis is initiated as a process of plant adaptation under salty environment condition ((Munns and Tester, (2008), Zewdie and Bosland, (2000)). Capsaicin is the active component with physiological and pharmacological properties (Sharma et al, 2013).

Capsicum species were introduced in Morocco through Europe in twenty century in context of adaptation trials of tropical crops repatriated from the conquest of the new world in the $16^{\text {th }}$ century. Some of spicy pepper adapted varieties to salt water irrigation stress were on-farm conserved through generations thanks to farmers' ingenuity. Fruits are consumed as a fresh or cooked vegetable, or used in food as condiment or as culinary supplement to enhance food coloring and pungent flavor. Crop adaptability and fruits pungency strength are the primary farmers' sought criteria that strengthen seeds and seedlings exchange among farmers. The hot pepper landrace of Maleh valley have acquired a notoriety related to its specific adaptation to salt environment and fruit phenotypic traits, organoleptic quality and pungency.

Thus, taking in account socio-economic factors, the present study was undertaken to assess fruits quality of hot pepper produced in Maleh valley using fruit phenotypic traits, biochemical composition and pungency strength. The expected results may help farmers to identify promising genotypes.

\section{Material and Methods}

\subsection{Plant Materials}

Eighteen accessions of hot pepper landrace cultivated in Maleh valley were randomly collected in farmers' field across three target localities during 2014-2015 growing season; Sidi Moussa Ben Ali (SMB/Site ${ }_{1}$; O $7^{\circ} 22^{\prime}, 33^{\circ} 35^{\prime}$ $\mathrm{N})$, Ech-challalate $\left(\mathrm{ECH} / \mathrm{Site}_{2} ; \mathrm{O}^{\circ} 24^{\prime}, 33^{\circ} 38^{\prime}\right)$ and Sidi Moussa El Majdoub (SME/Site ${ }_{3}$; O $7^{\circ} 23^{\prime}, 33^{\circ} 37^{\prime} \mathrm{N}$ ). Maleh valley is characterized by an average of annual temperature of $18^{\circ} \mathrm{C}$ with a mean maximum of $23^{\circ} \mathrm{C}$ between June and September coinciding with pepper flowering and fruit maturity. The soil contains 1 to $5 \mathrm{~g} / \mathrm{l}$ of dry residue of salts due to saline irrigation water (El Ouali, 1997). Six plant samples were randomly selected along farmers' field diagonal at regular intervals. From each plant, eight ripe fruits per plant were characterized using phenotypical traits. Chemical components were analyzed from pericarp of the hot pepper fruit samples characterized per field of farmer. It should be noted that on the basis of the survey data, farmers using the same genetic material (seed exchange) were represented by only one and the number of farmer fields sampled is proportional to the total area of the site. In addition, some samples of water irrigation were analyzed for $\mathrm{NaCl}$ concentration.

\subsection{Phenotypical Characterization}

Eight qualitative characters based on fruit features traits were measured following CPVO protocol CPVO-TP/076/2 according to UPOV Guideline TG/76/8 (2010) (Table 1).

Table 1. Descriptors of morphological qualitative traits

\begin{tabular}{|c|c|c|}
\hline $\mathrm{N}^{\circ}$ & Phenotypical characters & Notation \\
\hline 1 & Anthocyanin coloration of nodes & 0: Absent, 3: Slight, 5: Medium, 7: Strong \\
\hline 2 & Fruit attitude & 1: Erect, 2: Horizontal, 3: Drooping \\
\hline 3 & Fruit shape & 6: Trapezoidal, 7: Moderately triangular, 8: Narrowly triangular, 9: Horn shaped \\
\hline 4 & Texture of pericarp surface & 3: Smooth, 5: Slightly wrinkled, 7: Strongly wrinkled \\
\hline 5 & Sinuation of pericarp & 0: Absent or very weak, 3: Weak, 5: Medium, 7: Strong. 9: Very strong \\
\hline 6 & Red color intensity of fruit & 3: Light, 5: Medium, 7: Dark \\
\hline 7 & Brightness of fruit red color & 3: Low shine, 5: Medium, 7: Strong Shine \\
\hline 8 & Shape of fruit apex & 1: Very acute, 2: Moderately acute, 3: Rounded, $4:$ Moderately depressed, 5: Very depressed \\
\hline
\end{tabular}




\subsection{Chemical Analysis}

\subsubsection{Dry Matter and Ash Content (\%)}

Dry matter content $(\%)$ was determined by drying $5 \mathrm{~g}$ pepper homogenate to a constant weight at $105^{\circ} \mathrm{C}$ during 48 hours until a constant mass. Ash content (\%) was determined by ashing the residue from moisture determination in an oven at $500 \pm 50^{\circ} \mathrm{C}$ during five hours (ISO 928: spices and condiments).

\subsubsection{Determination of Total Carbohydrates}

Carbohydrate content was measured according to the method of Yemm and Willis (1954) using anthrone reagent. Sugars were firstly extracted from dried fruit pericarp of hot pepper with aqueous ethanol $80 \%$ at $45^{\circ} \mathrm{C}$, followed by centrifugation at $5000 \mathrm{rpm}$ for $10 \mathrm{~min}$. In $200 \mu \mathrm{l}$ of the extract, $50 \mu 1$ of the $10 \%$ anthrone reagent dissolved in Sulphuric acid was added and boiled at $100^{\circ} \mathrm{C}$ for 30 minutes. Absorbance was determined by spectrophotometer at 620nm (Osborne DR, 1986). Glucose was the used standard. The optical density of glucose solutions ( 0 to $10 \mathrm{mg}$ glucose $/ 10 \mathrm{~mL}$ solution) was plotted on the standard straight line. The quantitative determination of total carbohydrate content was expressed as $\mathrm{mg} / \mathrm{g}$ fresh weigh (FW) using the formula: $\mathrm{Y}=$ $0.576 \mathrm{x}-0.065\left(\mathrm{R}^{2}=0.835\right)$.

\subsubsection{Lipids Extraction and Analysis}

Total fatty acid content and fatty acid composition were determined in pericarp of hot pepper fruit samples. The analysis consisted on preparing first the Fatty Acid Methyl Ester (FAME) and secondly quantifying by chromatographic analysis (GC/MS 480). The FAME was prepared from the lipids extracted from samples by heating with heptane during seven hours. Lipids $(0.2 \mathrm{~g})$ were converted into fatty acid methyl esters (FAME) to determine fatty acid composition. The FAME was separated using a gas chromatograph and fatty acids composition was quantified using the retention times compared to those of the used standards (NIST, 2011). A capillary column of high polarity fused silica was used (length $30 \mathrm{~m}$; internal diameter $0.32 \mathrm{~mm}$; thickness of the film $0.25 \mu \mathrm{m}$ ). The flow of carrier gas (Helium) was $11 / \mathrm{min}$. The injector temperature was $250^{\circ} \mathrm{C}$ and the detector temperature was $300^{\circ} \mathrm{C}$. The starting temperature of the oven was $80^{\circ} \mathrm{C}$ and was increased at a rate of $3^{\circ} \mathrm{C} / \mathrm{min}$ until $220^{\circ} \mathrm{C}(7 \mathrm{~min})$. The injection volume was $1 \mu \mathrm{l}$ and a blank was run after every analyses. The peak areas were determined and the concentrations of fatty acids were expressed in $\mathrm{g} / 100 \mathrm{~g}$ of total lipids (Figure 1). The most abundant fatty acids in the pericarp of hot pepper fruits were palmitic acid (16:0), oleic acid (18:1n-9) and linoleic (18:2n-6) acid.

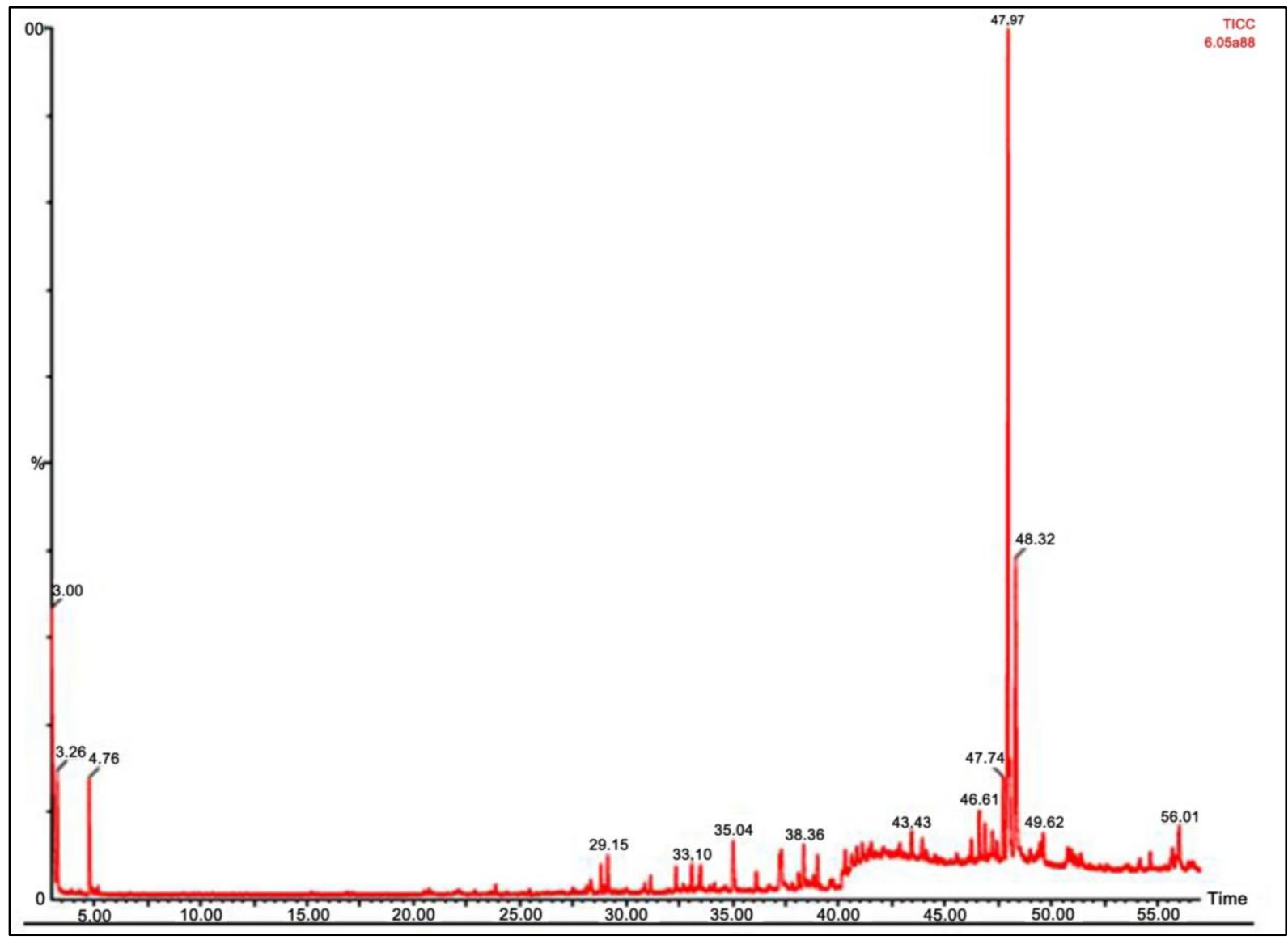

Figure 1. Chromatogram of fatty acids composition 


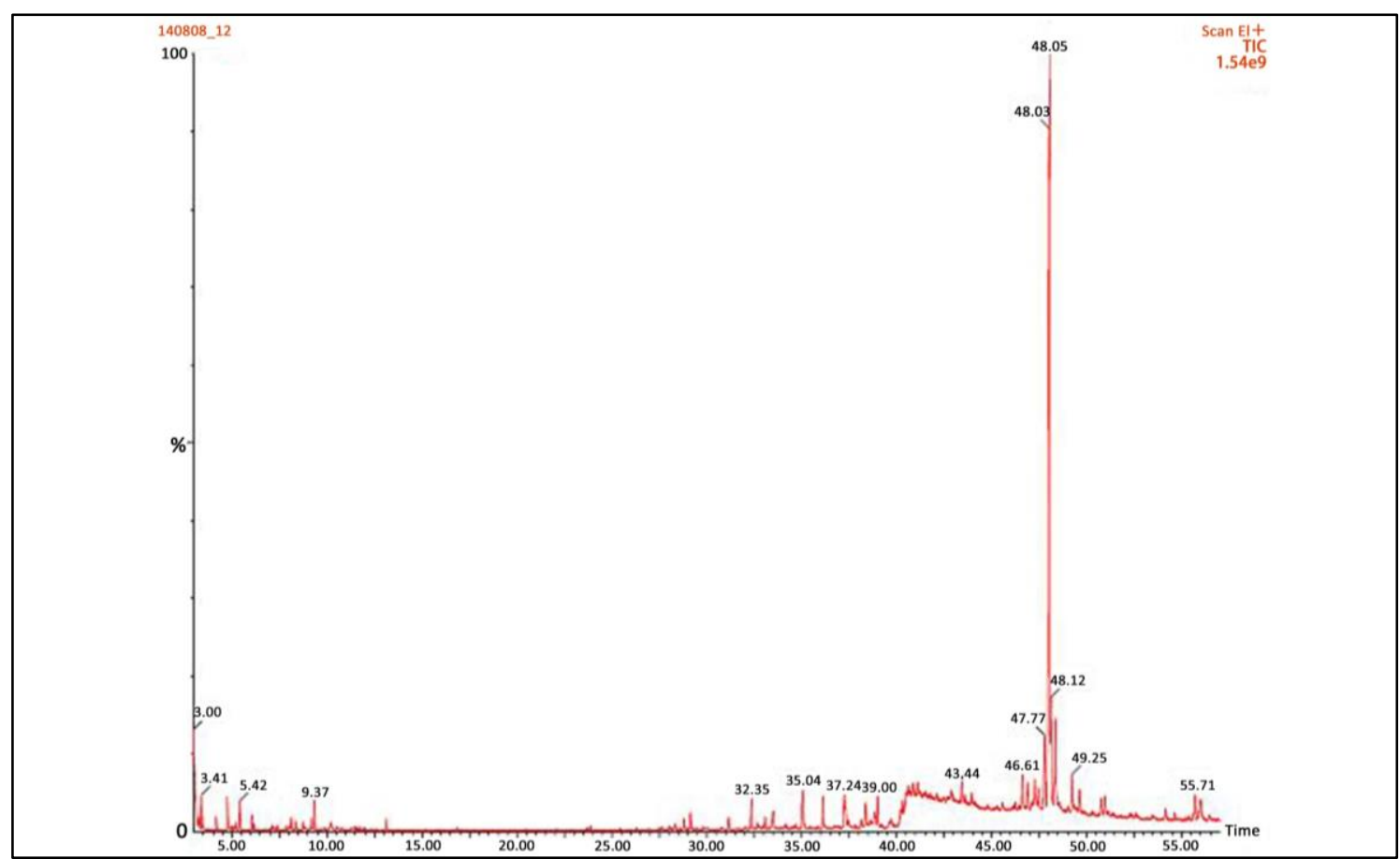

Figure 2. Chromatogram of Capsaicinoids composition

\subsubsection{Determination of Total Phenolic Content}

Total phenolic content were analyzed spectrophotometrically using Folin-Ciocalteau colorimetric method (Slinkard et Singelton, 1977). Each dried fruit pericarp sample $(2 \mathrm{~g})$ was extracted with $10 \mathrm{ml}$ of $80 \%$ ethanol. Volume of $0.1 \mathrm{ml}$ of the extract was mixed with $0.25 \mathrm{ml}$ of $50 \%$ Folin-Ciocalteu reagent and let stand for $5 \mathrm{~min}$ at $25^{\circ} \mathrm{C}$. Then, $0.25 \mathrm{ml}$ of $20 \%$ sodium carbonate solution was added to $2 \mathrm{ml}$ of distilled water in a test tube. Each sample was let standing for $60 \mathrm{~min}$ at room temperature in the dark. Then, the absorbance was measured at $760 \mathrm{~nm}$ using UV-visible spectrophotometer model PG Instrument +80 , (Leicester, UK). The total phenolic content was expressed as $\mathrm{mg}$ of Gallic acid per $100 \mathrm{~g}$ fresh weigh $(\mathrm{FW})$ of hot pepper fruit pericarp using the following formula: $\mathrm{Y}=1.216 \mathrm{x}-0.008\left(\mathrm{R}^{2}=0.93\right)$.

\subsubsection{Capsaicinoid Extraction and Analysis}

Capsaicinoid extraction was made following Collins et al. (1995) method using ethanol $99.8 \%$ on dried fruit pericarp of hot pepper samples. Quantitative concentration of Capsaicinoid components was analyzed using High Performance Liquid Chromatography (HPLC). Capsaicinoid concentration in fruit samples was expressed as $\mathrm{mg} / \mathrm{g}$ of dry matter (DM). The major quantitative components of Capsaicinoid are capsaicin (48.03mn) and dihydro-capsaicin (48.05mn). Capsaicin and dihydro-capsaicin of each sample were separated, identified and quantified using retention times respectively for capsaicin (7.0 $\mathrm{min})$ and dihydro-capsaicin (10.0min) compared to standard under the same conditions (figure 2). The pungency strength of samples was evaluated based on capsaicinoids with the equivalent value of $16.110^{6}$ Scoville Heat Unit (SHU) (Dong, (2000).

\subsection{Statistics Analysis}

Qualitative traits diversity among spicy pepper accessions from Maleh valley was assessed using frequency of each phenotypic trait. In addition, a matrix was generated on the base of these qualitative traits. The analysis of molecular variance (AMOVA) was used to assess genetic diversity within accessions, among accessions and among populations (sites) by spatial scale. Genetic diversity was assessed through Shannon-Weaver's genetic diversity Index (SWI) (Shannon and Weave, 1949) and the percentage of polymorphism (\%P). All the measurements were assessed and represented as mean and standard error (SE). The genetic differentiation (PhiPT) and Nei genetic distance index (NeiGD) were calculated between pairwise accessions or pairwise populations (site) as the proportion of the variance among accessions/populations relative to the total variance (Nei M., 1973). Derived diversity of each accession was measured independently of sample size (n) as sums of squares (SSWP) divided by (n-1). The Nei genetic distance matrix of qualitative traits was subjected to a hierarchical Cluster built on the basis of similarity and dissimilarity index among accessions calculated by Unweighted Pair Group of Arithmetic (UPGMA) method of GenStat (version 12.2, 2010). Regarding data of biochemical components, ANOVA analysis indicate significant differences ( $p$-value $\alpha \leq 0.05$ ) between the mean values of accessions and sites. 
Table 2. Frequency distribution of eight qualitative traits among hot pepper landrace of Maleh valley by site scale and their genetic parameters

\begin{tabular}{|c|c|c|c|c|c|c|}
\hline \multirow{2}{*}{\multicolumn{2}{|c|}{ Qualitative traits }} & \multicolumn{3}{|c|}{ Frequency (\%) } & \multirow{3}{*}{$\begin{array}{c}\begin{array}{c}\text { Polymorphic } \\
\text { rate }(\% \mathrm{P})\end{array} \\
\\
23.6 \pm 6.5 \\
(0.0-75.0)\end{array}$} & \multirow{3}{*}{$\begin{array}{c}\begin{array}{c}\text { Genetic } \\
\text { diversity index } \\
\text { (SWI) }\end{array} \\
0.130 \pm 0.03 \\
(0-0.357)\end{array}$} \\
\hline & & \multirow{2}{*}{$\begin{array}{c}\text { Site }_{1} \\
20.8^{* *} \\
0.0^{\text {ns }} \\
70.8^{* * *} \\
8.33^{\text {ns }}\end{array}$} & \multirow{2}{*}{$\begin{array}{l}\text { Site }_{2} \\
20.0^{\ldots-} \\
6.67^{\text {ns }} \\
46.7^{\text {ns }} \\
26.7^{*}\end{array}$} & \multirow{2}{*}{$\begin{array}{c}\text { Site }_{3} \\
66.7^{m+*} \\
0.0^{\text {ns }} \\
24.1^{\cdots} \\
9.26^{\text {ns }}\end{array}$} & & \\
\hline $\begin{array}{l}\text { Intensity of nodes } \\
\text { anthocyanin } \\
\text { coloration }\end{array}$ & \begin{tabular}{|l|} 
Absent \\
Slight \\
Medium \\
Strong
\end{tabular} & & & & & \\
\hline Fruit attitude & $\begin{array}{l}\text { Horizontal } \\
\text { drooping }\end{array}$ & $\begin{array}{l}66.7^{\mathrm{ns}} \\
33.3^{\mathrm{ns}}\end{array}$ & $\begin{array}{l}83.3^{\text {ns }} \\
16.7^{\text {ns }}\end{array}$ & $\begin{array}{l}72.2^{\text {ns }} \\
27.8^{\text {ns }}\end{array}$ & $\begin{array}{l}44.4 \pm 7.6 \\
(0.0-66.7)\end{array}$ & $\begin{array}{c}0.260 \pm 0.04 \\
(0-0.403)\end{array}$ \\
\hline Fruit Shape & $\begin{array}{l}\text { Trapezoidal } \\
\text { Moderately triangular } \\
\text { Narrowly triangular } \\
\text { Horn shaped }\end{array}$ & $\begin{array}{l}0.00^{\text {ns }} \\
1.23^{\cdots} \\
92.0^{*} \\
6.75^{\cdots}\end{array}$ & $\begin{array}{l}0.94^{\text {ns }} \\
8.96^{\text {ns }} \\
88.7^{\text {ns }} \\
1.42^{\text {ns }}\end{array}$ & $\begin{array}{l}0.26^{\text {ns }} \\
12.9^{\cdots} \\
85.0^{\text {ns }} \\
1.81^{\text {ns }}\end{array}$ & $\begin{array}{l}34.7 \pm 7.0 \\
(0.0-75.0)\end{array}$ & $\begin{array}{c}0.132 \pm 0.03 \\
(0-0.325)\end{array}$ \\
\hline $\begin{array}{l}\text { Texture of fruit } \\
\text { surface }\end{array}$ & $\begin{array}{l}\text { Smooth } \\
\text { Slightly wrinkled } \\
\text { Strongly wrinkled }\end{array}$ & $\begin{array}{l}20.3^{\cdots} \\
65.6^{\text {ns }} \\
14.1^{\cdots}\end{array}$ & $\begin{array}{l}32.6^{\text {ns }} \\
59.0^{\text {ns }} \\
8.49^{*-}\end{array}$ & $\begin{array}{c}40.4^{\cdots} \\
59.6^{n s} \\
0.0^{\ldots}\end{array}$ & $\begin{array}{c}53.7 \pm 8.6 \\
(0.0-100.0)\end{array}$ & $\begin{array}{c}0.270 \pm 0.04 \\
(0-0.452)\end{array}$ \\
\hline $\begin{array}{l}\text { Intensity of fruit red } \\
\text { color }\end{array}$ & $\begin{array}{l}\text { Light } \\
\text { Medium } \\
\text { Dark }\end{array}$ & $\begin{array}{l}30.7^{\cdots} \\
22.7^{\cdots} \\
46.6^{\text {ns }}\end{array}$ & $\begin{array}{l}2.83^{\cdots+} \\
29.3^{\ldots+} \\
67.9^{m *}\end{array}$ & $\begin{array}{l}13.2^{\mathrm{ns}} \\
55.7^{\mathrm{m}} \\
31.1^{\cdots}\end{array}$ & $\begin{array}{c}44.4 \pm 8.9 \\
(0.0-100.0)\end{array}$ & $\begin{array}{c}0.218 \pm 0.04 \\
(0-0.477)\end{array}$ \\
\hline Fruit Brightness & $\begin{array}{l}\text { High } \\
\text { Medium } \\
\text { Low }\end{array}$ & $\begin{array}{l}80.4^{m+*} \\
17.2^{-*} \\
2.45^{\text {ns }}\end{array}$ & $\begin{array}{l}70.8^{* * *} \\
26.4^{\cdots *} \\
2.83^{\text {ns }}\end{array}$ & $\begin{array}{l}32.4^{\ldots+} \\
65.5^{\mathrm{mw}} \\
2.07^{\mathrm{ns}}\end{array}$ & $\begin{array}{l}25.9 \pm 7.9 \\
(0.0-66.7)\end{array}$ & $\begin{array}{c}0.119 \pm 0.03 \\
(0-0.381)\end{array}$ \\
\hline $\begin{array}{l}\text { Sinuation of } \\
\text { pericarp }\end{array}$ & \begin{tabular}{|l|} 
Absent \\
Weak \\
Medium \\
Strong \\
\end{tabular} & $\begin{array}{l}58.3^{\text {ns }} \\
28.8^{\text {ns }} \\
11.0^{\text {ns }} \\
1.84^{*}\end{array}$ & $\begin{array}{l}73.1^{m-*} \\
23.1^{*} \\
3.30^{\cdots-} \\
0.47^{\text {ns }}\end{array}$ & $\begin{array}{l}56.7^{\mathrm{mm}} \\
32.6^{*} \\
10.6^{*} \\
0.0^{\mathrm{ns}}\end{array}$ & $\begin{array}{c}55.6 \pm 3.1 \\
(40.0-80.0)\end{array}$ & $\begin{array}{c}0.246 \pm 0.03 \\
(0.162-0.296)\end{array}$ \\
\hline Shape of fruit Apex & \begin{tabular}{|l|} 
Rounded \\
Moderately depressed \\
Very depressed
\end{tabular} & $\begin{array}{l}92.0^{\text {ns }} \\
2.45^{\cdots} \\
5.52^{\text {ns }}\end{array}$ & $\begin{array}{c}90.5^{\text {ns }} \\
0.0^{\text {ns }} \\
9.48^{* *}\end{array}$ & $\begin{array}{l}95.1^{* \prime} \\
0.0^{\text {ns }} \\
4.92^{\text {ns }}\end{array}$ & $\begin{array}{l}18.9 \pm 5.2 \\
(0.0-6.0)\end{array}$ & $\begin{array}{c}0.079 \pm 0.02 \\
(0-0.217)\end{array}$ \\
\hline
\end{tabular}

Test of $\mathrm{khi}^{2}$ (ns: not significant at $\left.\alpha=0.10\right)$; (*: significant at $\left.\alpha=0.10\right)$; (**: significant at $\left.\alpha=0.05\right)$; (***: significant at $\alpha=0.10$ )

\section{Results and Discussion}

\subsection{Morphological Qualitative Traits}

The frequency distribution of eight qualitative characters showed a wide variation among sites and among accessions of Maleh hot pepper. The predominated qualitative traits as listed in table 2 include rounded fruit apex, narrowly triangular fruit shape and high to medium fruits brightness. These results are argued with genetic parameters as polymorphism rate $(\mathrm{P})$ and Shannon genetic diversity index (SWI). These results highlight farmers' selection impact on fruit feature to increase market adding value since the crop constitutes a source of incomes for households. Whereas, wide variation was recorded for fruit pedicel position, texture of fruit surface, fruit red color and sinuation of pericarp regarding the distribution of traits frequency and genetic parameters. Our finding are in accordance with Nsabiyera et al. (2013) study on hot pepper collection from Uganda that found high genetic index for texture of fruit surface and low index for fruit shape.

The lowest genetic diversity was recorded for $E_{7}$ accession followed by $\mathbf{M}_{1}$ accession (Table 3). The individual genotypes of both $\mathrm{E}_{7}$ and $\mathrm{M}_{1}$ accessions are homogeneously and similarly characterized by drooping fruits attitude, narrowly triangular fruits shape with rounded apex, slightly wrinkled of fruit pericarp texture without rippling, and are distinguished in regards of fruits color intensity and brightness. Fruits of $E_{7}$ were characterized with dark-red color associated with low shining brightness while those of $\mathrm{M}_{1}$ were characterized with medium intensity of red color and shining brightness.

Contrarily, genetic parameters revealed wide diversity within $\mathrm{E}_{4}, \mathrm{E}_{5}, \mathrm{E}_{6}, \mathrm{M}_{6}$ and $\mathrm{B}_{3}$ accessions (Table 3). These accessions might include potential genotypes for improving plant productivity potential and fruits feature to satisfy both farmers and consumers requirements. The variability of phenotypic traits might be attributed to the effects of genotype, environment and interaction of genotype $\mathrm{x}$ environment, and could be affected by growing practice and fruit maturing stage (Bozokalfa et al. 2009).

The unripe fruit color was green with different level of color intensity ranging from light to dark, whereas ripe fruit color was red varying from light to dark. The consumers' attractive fruits color was red dark color with high brightness. The pigment color of pepper ripe fruit is controlled by three loci c-1, c-2 and y respectively for red, orange or yellow color with a domination of red color. Those genes regulate carotenoids synthesis level particularly ß-carotene and ß-cryptoxanthin (Popovsky and Paran, 2000). The observed variation of brilliant red color intensity among hot pepper accessions of Maleh valley is therefore related to the variable genetic expression patterns 
within the capsanthin and capsorubin synthase activity according to Popovsky and Paran, (2000) study.

Furthermore, ANOVA evidenced wider genetic variability within accessions (52\%) and among accessions $(43 \%)$ than among sites $(5 \%)$ (Table 4$)$ suggesting a strong seed or seedlings exchange network between pepper producers at Maleh valley scale. This result was argued by low genetic differentiation among sites (PhiRT $=0,045^{* * *}$ ) and supported by no significant variation revealed for derived diversity (SSWP/ (n-1)) between sites (Table 4). However, a substantial genetic differentiation among accessions (PhiPR $=0,453^{* * *}$ ) and within accessions $\left(\mathrm{PhiPT}=0,477^{* * * *}\right)$ was revealed. Indeed, derived genetic diversity (SSWP/(n-1)) has varied from 0.52 for $\mathrm{E}_{7}$ accession to 3.05 for $\mathrm{E}_{4}$ accession (Table 3). These results support traits frequency distribution among sites (Table 2) and are confirmed by genetic parameters of qualitative characters among accessions listed in Table 3.

Table 3. Genetic parameters of morphological qualitative traits variation among Maleh hot pepper accessions

\begin{tabular}{|c|c|c|c|c|c|c|}
\hline \multirow{2}{*}{\multicolumn{2}{|c|}{ Qualitative traits }} & \multicolumn{3}{|c|}{ Frequency (\%) } & \multirow{2}{*}{$\begin{array}{l}\text { Polymorphic } \\
\text { rate }(\% \mathrm{P})\end{array}$} & \multirow{2}{*}{$\begin{array}{c}\text { Genetic } \\
\text { diversity index } \\
\text { (SWI) }\end{array}$} \\
\hline & & Site $_{1}$ & Site $_{2}$ & $\mathrm{Site}_{3}$ & & \\
\hline $\begin{array}{l}\text { Intensity of nodes } \\
\text { anthocyanin } \\
\text { coloration }\end{array}$ & $\begin{array}{l}\text { Absent } \\
\text { Slight } \\
\text { Medium } \\
\text { Strong }\end{array}$ & $\begin{array}{c}20.8^{* *} \\
0.0^{\text {ns }} \\
70.8^{* * *} \\
8.33^{\text {ns }}\end{array}$ & $\begin{array}{l}20.0^{\cdots *} \\
6.67^{\text {ns }} \\
46.7^{\text {ns }} \\
26.7^{*}\end{array}$ & $\begin{array}{l}66.7^{\text {mit }} \\
0.0^{\text {ns }} \\
24.1^{\ldots} \\
9.26^{\text {ns }}\end{array}$ & $\begin{array}{l}23.6 \pm 6.5 \\
(0.0-75.0)\end{array}$ & $\begin{array}{c}0.130 \pm 0.03 \\
(0-0.357)\end{array}$ \\
\hline Fruit attitude & $\begin{array}{l}\text { Horizontal } \\
\text { drooping }\end{array}$ & $\begin{array}{l}66.7^{\mathrm{ns}} \\
33.3^{\mathrm{ns}}\end{array}$ & $\begin{array}{l}83.3^{\text {ns }} \\
16.7^{\text {ns }}\end{array}$ & $\begin{array}{l}72.2^{\text {ns }} \\
27.8^{\text {ns }}\end{array}$ & $\begin{array}{l}44.4 \pm 7.6 \\
(0.0-66.7)\end{array}$ & $\begin{array}{c}0.260 \pm 0.04 \\
(0-0.403)\end{array}$ \\
\hline Fruit Shape & $\begin{array}{l}\text { Trapezoidal } \\
\text { Moderately triangular } \\
\text { Narrowly triangular } \\
\text { Horn shaped }\end{array}$ & $\begin{array}{c}0.00^{\text {ns }} \\
1.23^{\cdots} \\
92.0^{\circ} \\
6.75^{\cdots}\end{array}$ & $\begin{array}{l}0.94^{n s} \\
8.96^{n s} \\
88.7^{\text {ns }} \\
1.42^{\text {ns }}\end{array}$ & $\begin{array}{l}0.26^{\text {ns }} \\
12.9^{\cdots} \\
85.0^{\text {ns }} \\
1.81^{\text {ns }}\end{array}$ & $\begin{array}{l}34.7 \pm 7.0 \\
(0.0-75.0)\end{array}$ & $\begin{array}{c}0.132 \pm 0.03 \\
(0-0.325)\end{array}$ \\
\hline $\begin{array}{l}\text { Texture of fruit } \\
\text { surface }\end{array}$ & $\begin{array}{l}\text { Smooth } \\
\text { Slightly wrinkled } \\
\text { Strongly wrinkled }\end{array}$ & $\begin{array}{l}20.3^{\cdots} \\
65.6^{\mathrm{ns}} \\
14.1^{\cdots}\end{array}$ & $\begin{array}{l}32.6^{\text {ns }} \\
59.0^{\text {ns }} \\
8.49^{*-}\end{array}$ & $\begin{array}{c}40.4^{\cdots-} \\
59.6^{n s} \\
0.0^{\ldots-}\end{array}$ & $\begin{array}{c}53.7 \pm 8.6 \\
(0.0-100.0)\end{array}$ & $\begin{array}{c}0.270 \pm 0.04 \\
(0-0.452)\end{array}$ \\
\hline $\begin{array}{l}\text { Intensity of fruit red } \\
\text { color }\end{array}$ & $\begin{array}{l}\text { Light } \\
\text { Medium } \\
\text { Dark }\end{array}$ & $\begin{array}{l}30.7^{\cdots} \\
22.7^{\cdots} \\
46.6^{\mathrm{ns}}\end{array}$ & $\begin{array}{l}2.83^{\ldots+} \\
29.3^{\ldots+} \\
67.9^{\ldots *}\end{array}$ & $\begin{array}{l}13.2^{\text {ns }} \\
55.7^{m *} \\
31.1^{\ldots}\end{array}$ & $\begin{array}{c}44.4 \pm 8.9 \\
(0.0-100.0)\end{array}$ & $\begin{array}{c}0.218 \pm 0.04 \\
(0-0.477)\end{array}$ \\
\hline Fruit Brightness & $\begin{array}{l}\text { High } \\
\text { Medium } \\
\text { Low }\end{array}$ & $\begin{array}{l}80.4^{m+m} \\
17.2^{m} \\
2.45^{\text {ns }}\end{array}$ & $\begin{array}{l}70.8^{\cdots *} \\
26.4^{\ldots *} \\
2.83^{\text {ns }}\end{array}$ & $\begin{array}{l}32.4^{\text {a* }} \\
65.5^{\mathrm{m*}} \\
2.07^{\mathrm{ns}}\end{array}$ & $\begin{array}{l}25.9 \pm 7.9 \\
(0.0-66.7)\end{array}$ & $\begin{array}{c}0.119 \pm 0.03 \\
(0-0.381)\end{array}$ \\
\hline $\begin{array}{l}\text { Sinuation of } \\
\text { pericarp }\end{array}$ & $\begin{array}{l}\text { Absent } \\
\text { Weak } \\
\text { Medium } \\
\text { Strong }\end{array}$ & $\begin{array}{l}58.3^{\text {ns }} \\
28.8^{\text {ns }} \\
11.0^{\text {ns }} \\
1.84^{* *}\end{array}$ & $\begin{array}{l}73.1^{m+} \\
23.1^{*} \\
3.30^{\circ-} \\
0.47^{\text {ns }}\end{array}$ & $\begin{array}{l}56.7^{+1 *} \\
32.6^{*} \\
10.6^{*} \\
0.0^{\text {ns }}\end{array}$ & $\begin{array}{c}55.6 \pm 3.1 \\
(40.0-80.0)\end{array}$ & $\begin{array}{c}0.246 \pm 0.03 \\
(0.162-0.296)\end{array}$ \\
\hline Shape of fruit Apex & $\begin{array}{l}\text { Rounded } \\
\text { Moderately depressed } \\
\text { Very depressed }\end{array}$ & $\begin{array}{l}92.0^{\mathrm{ns}} \\
2.45^{\ldots} \\
5.52^{\mathrm{ns}}\end{array}$ & $\begin{array}{l}90.5^{\text {ns }} \\
0.0^{\text {ns }} \\
9.48^{*}\end{array}$ & $\begin{array}{l}95.1^{* \prime} \\
0.0^{\mathrm{ns}} \\
4.92^{\mathrm{ns}}\end{array}$ & $\begin{array}{l}18.9 \pm 5.2 \\
(0.0-6.0)\end{array}$ & $\begin{array}{c}0.079 \pm 0.02 \\
(0-0.217)\end{array}$ \\
\hline
\end{tabular}

Table 4. Genetic differentiation of hot pepper meta-population subdivisions

\begin{tabular}{|l|c|c|c|c|c|c|c|c|}
\hline Source & df & SS & MS & Est. Var. & $\%$ & Phi & Phi' & Phi max \\
\hline Among Sites (RT) & 2 & 218,211 & 109,105 & 0,165 & $4,5 \%$ & $0,045 * * *$ & 0,059 & 0,765 \\
\hline Among Accessions (PR) & 15 & 1039,062 & 69,271 & 1,597 & $43,3 \%$ & $0,453 * * *$ & 0,520 & 0,872 \\
\hline Within Accessions & 743 & 1433,106 & 1,929 & 1,929 & $52,3 \%$ & - & - & - \\
\hline Total (PT) & 760 & 2690,378 & & 3,691 & $100,0 \%$ & $0,477 * * *$ & - & - \\
\hline
\end{tabular}

Df: degree of freedom; SS: Sum square; MS: Mean square; Est. Var.: estimation of variance; \%: percentage of variability; Phi: genetic differentiation parameter, Phi': proportion of Phi relative to the maximum variability proportion attainable (Phi max) 


\subsection{Hierarchical Cluster Analysis of Morphological Qualitative Fruits Traits}

Five clusters were revealed at $94 \%$ of phenotypic traits similarity (Figure 3). The first cluster $\left(\mathrm{G}_{1}\right)$ gathered $\mathrm{E}_{6}$ accession $\left(\right.$ Site $\left._{2}\right)$ and $\mathrm{M}_{6}, \mathrm{M}_{7}$ and $\mathrm{M}_{9}$ accessions $\left(\right.$ Site $\left._{3}\right)$ characterized by similar fruit characteristics. Genetic distance between these accessions was low (0.023-0.079) suggesting a strong seed or seedling exchange among Site $_{3}$ and between $\mathrm{Site}_{2}$ and $\mathrm{Site}_{3}$. Genotypes of this group are characterized mainly by narrowly triangular fruit shape with slightly wrinkled surface texture, medium red color and brightness, rounded fruit apex and no sinuation of pericarp. The second group $\left(\mathrm{G}_{2}\right)$ was represented by a single accession of $B_{1}$ which was genetically distant from Site $_{1}$ accessions (0.150-0.194), Site $_{2}$ accessions (0.084-0.244) and $\mathrm{Site}_{3}$ accessions (0.054-0.191) (Figure 3). Individual genotypes of $B_{1}$ accession was distinguished by the homogenous traits of fruits such as narrowly triangular fruit shape $(100 \%)$ with rounded apex of fruit $(100 \%)$, light red color $(100 \%)$ associated with medium brightness $(100 \%)$, and pericarp without or with weak sinuation $(100 \%)$. The third $\left(\mathrm{G}_{3}\right)$ and fifth $\left(\mathrm{G}_{5}\right)$ clusters grouped each one accessions of $\mathrm{Site}_{3}$ suggesting a genetic diversification at $\mathrm{Site}_{3}$ scale. Accessions grouped in the same cluster were genetically closer respectively (0.017-0.67) and (0.018-0.055) (Table 5). The fourth cluster $\left(\mathrm{G}_{4}\right)$ might be subdivided in four sub-clusters at $97 \%$ of similarity. The two first sub-clusters grouped two accessions each from the same site respectively $\mathrm{Site}_{2}$ and Site $_{1}$ supporting genetic differentiation at site level. The third sub-clusters grouped two accessions genetically closer (0.023) originated from different site as $\mathrm{Site}_{2}$ and Site $_{1}$ supporting the seeds exchange among Site $_{2}-$ Site $_{1}$ looking for qualitative interest traits. Those accessions are homogenously characterized by narrowly triangular fruit shape $(100 \%)$ with rounded apex $(95 \%)$ and by dominance of such traits of drooping fruit insertion, dark red fruit color and low shining color, smooth to slightly wrinkled surface texture of fruits and absence of pericarp ripples. While fourth sub-cluster grouped a single accession $\left(\mathrm{E}_{7}\right)$ supposing high genetic distance between $\mathrm{E}_{7}$ and accessions gathered in other groups (Figure 3). The uniformity of qualitative traits (SWI=0.043) among genotypes of $\mathrm{E}_{7}$ accession is a consequence of strong farmers' selection impact. The high similarity of qualitative traits (94\%) among hot pepper accessions of Maleh valley might be attributed to environment adversity associated with farmers' selection impact add to a strong seed network exchange.

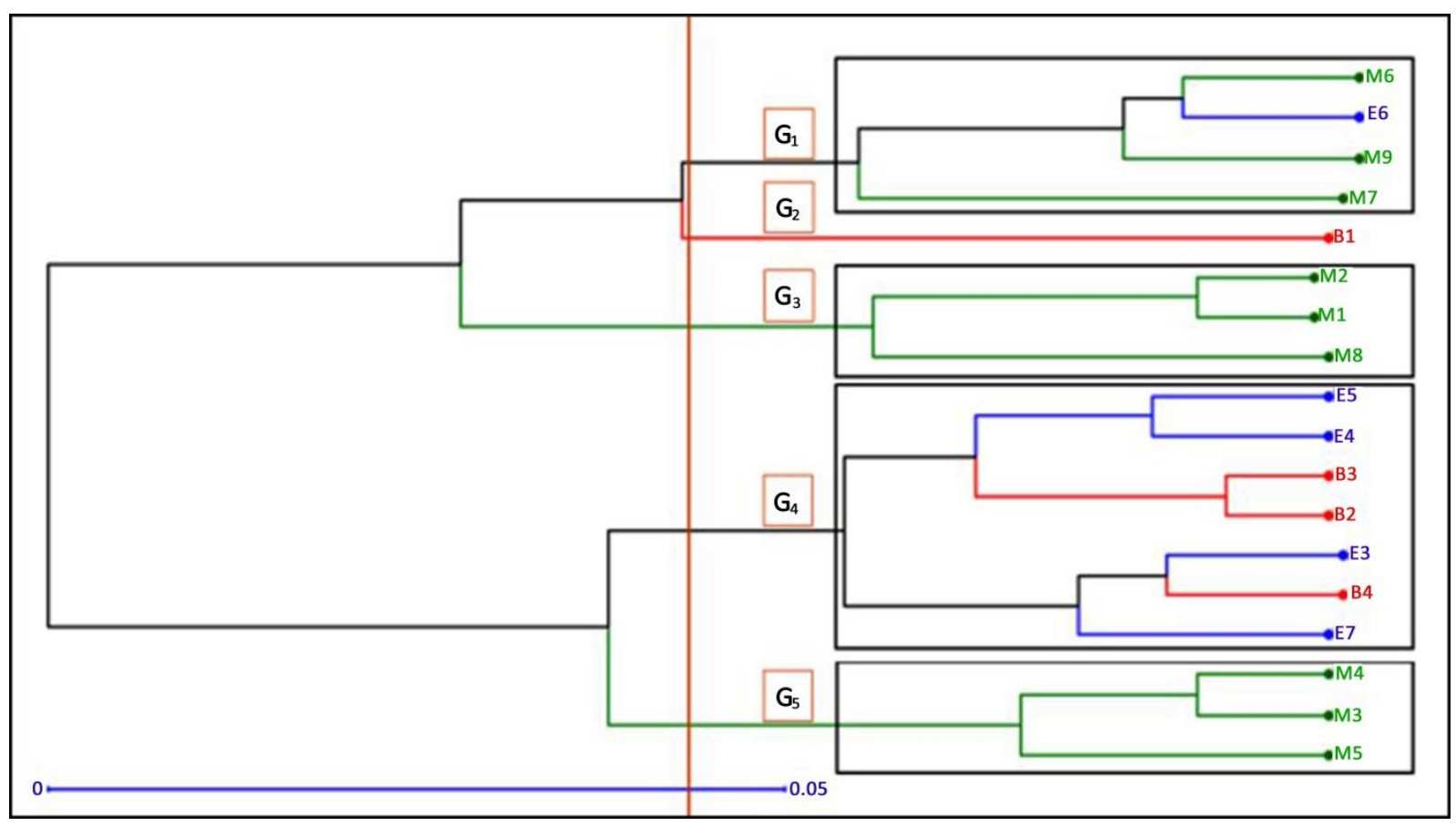

Figure 3. Hierarchical clustering based on genetic distance of fruits morphological qualitative traits 
Table 5. Genetic distance among accessions of spicy pepper phenotypical qualitative traits

\begin{tabular}{|c|c|c|c|c|c|c|c|c|c|c|c|c|c|c|c|c|c|c|}
\hline $\begin{array}{l}\text { Nei } \\
\text { GD }\end{array}$ & B1 & B2 & B3 & B4 & E3 & E4 & E5 & E6 & E7 & M1 & M2 & M3 & M4 & M5 & M6 & M7 & M8 & M9 \\
\hline $\begin{array}{l}\text { B1 } \\
\text { B2 }\end{array}$ & $\begin{array}{c}0 \\
0150\end{array}$ & & & & & & & & & & & & & & & & & \\
\hline B2 & 0,150 & 0 & & & & & & & & & & & & & & & & \\
\hline B3 & 0,167 & 0,014 & 0 & & & & & & & & & & & & & & & \\
\hline B4 & 0,194 & 0,057 & 0,046 & 0 & & & & & & & & & & & & & & \\
\hline E3 & 0,169 & 0,085 & 0,090 & 0,023 & 0 & & & & & & & & & & & & & \\
\hline E4 & 0,086 & 0,068 & 0,056 & 0,060 & 0,063 & 0 & & & & & & & & & & & & \\
\hline E5 & 0,133 & 0,044 & 0,024 & 0,032 & 0,052 & 0,025 & 0 & & & & & & & & & & & \\
\hline E6 & 0,084 & 0,199 & 0,178 & 0,193 & 0,195 & 0,092 & 0,148 & 0 & & & & & & & & & & \\
\hline E7 & 0,244 & 0,063 & 0,064 & 0,029 & 0,040 & 0,108 & 0,068 & 0,287 & 0 & & & & & & & & & \\
\hline M1 & 0,165 & 0,162 & 0,169 & 0,143 & 0,099 & 0,135 & 0,157 & 0,145 & 0,165 & 0 & & & & & & & & \\
\hline M2 & 0,138 & 0,145 & 0,157 & 0,168 & 0,117 & 0,119 & 0,141 & 0,139 & 0,189 & 0,017 & 0 & & & & & & & \\
\hline M3 & 0,191 & 0,120 & 0,131 & 0,085 & 0,078 & 0,114 & 0,093 & 0,192 & 0,094 & 0,229 & 0,207 & 0 & & & & & & \\
\hline M4 & 0,181 & 0,122 & 0,109 & 0,067 & 0,091 & 0,091 & 0,070 & 0,142 & 0,106 & 0,248 & 0,236 & 0,018 & 0 & & & & & \\
\hline M5 & 0,181 & 0,143 & 0,129 & 0,072 & 0,092 & 0,087 & 0,090 & 0,136 & 0,108 & 0,246 & 0,270 & 0,055 & 0,030 & 0 & & & & \\
\hline M6 & 0,054 & 0,202 & 0,190 & 0,208 & 0,205 & 0,109 & 0,152 & 0,023 & 0,297 & 0,150 & 0,129 & 0,184 & 0,145 & 0,166 & 0 & & & \\
\hline M7 & 0,096 & 0,184 & 0,189 & 0,164 & 0,139 & 0,105 & 0,161 & 0,039 & 0,226 & 0,097 & 0,120 & 0,166 & 0,150 & 0,106 & 0,064 & 0 & & \\
\hline M8 & 0,069 & 0,085 & 0,090 & 0,131 & 0,115 & 0,046 & 0,089 & 0,085 & 0,161 & 0,067 & 0,057 & 0,204 & 0,198 & 0,176 & 0,094 & 0,069 & 0 & \\
\hline M9 & 0,102 & 0,234 & 0,234 & 0,250 & 0,239 & 0,135 & 0,203 & 0,026 & 0,336 & 0,150 & 0,131 & 0,226 & 0,188 & 0,200 & 0,036 & 0,079 & 0,112 & 0 \\
\hline
\end{tabular}

\subsection{Nutritive Quality}

ANOVA analysis revealed the existence of highly significant effect of sites and accessions $(\mathrm{P}<0.05)$ for almost all analyzed chemical components.

\subsubsection{Dry Matter and Ash Content}

The water part in red spicy fruits of Maleh valley varied significantly among accessions and among sites between 88.2-89.9\% (Table 7). These values are close to the lowest values (90.46 - 92.87\%) mentioned by Bernardo et al, (2008) in traditional Spanish varieties of red fruits pepper, and lower than those reported in previous studies (94 to 97\%) by Simonne et al. (1997). The differences in water proportion in fruits might be attributed to low water availability in the production area of Maleh valley. Otherwise, many studies showed that water content decreased progressively during fruit ripening (Estrada et al. (2000); Bernardo et al, (2008)). Thus, water percentage in fruits might be affected by the environmental conditions and fruit stage maturity.

The average of total ash content $(3.42 \pm 0.07)$ varied among accessions from $2.80 \%\left(\mathrm{~B}_{3}\right)$ to $4.07 \%\left(\mathrm{E}_{6}\right)$. Our result is lower than those reported in the literature $(4.27-8.75 \%)$ by Bernardo et al, (2008) and Estrada et al, (2000).

\subsubsection{Carbohydrates Content}

Significant variation $(p<0.05)$ of carbohydrates concentration in spicy pepper fruits of Maleh valley $(53.2 \pm 2.0 \mathrm{mg} / \mathrm{g} \mathrm{FW})$ was observed among sites and among accessions that ranged respectively from $(41.8 \pm 2.3)$ Site $_{2}$ to $(61.2 \pm 1.9) \mathrm{Site}_{3}$ and from $37.5 \pm 0.7\left(\mathrm{E}_{6}\right)$ to $67.4 \pm 0.04$ $\left(\mathrm{M}_{8}\right)$ (Table 7). These values are similar to those obtained by Bernardo et al, (2008) in Spanish traditional varieties of pepper $(64.5 \mathrm{~g} / 100 \mathrm{~g} \mathrm{DW})$. The significant differences $(\mathrm{P}<$ 0.05 ) in total carbohydrates concentration in ripe fruits among studied accessions and sites suggested genetic and environmental effects. The carbohydrates represent in human nutrition the most important source of energy among the macronutrients providing 40 to $80 \%$ of total energy intake. Their dietary roles are therefore related to stored source of energy and transport in addition to their involvement in structuring novel molecules from the primary carbon skeleton they constitute.

\subsubsection{Total Lipids and Fatty Acid Composition}

Total lipids content of Maleh pepper spicy fruits accessions averaged among sites from 1.20 (Site 3 ) to 1.42 $\left(\mathrm{Site}_{2}\right)$ and varied significantly among accessions from $1.11\left(\mathrm{M}_{5}\right)$ to $1.54\left(\mathrm{E}_{6}\right) \mathrm{g} / 100 \mathrm{~g}$ of ripe fruits DW (Table 6). Our result revealed that fruits of Maleh hot pepper are considered as poor sources of lipids (less than 2\%). This result is in accordance with those found by Bernardo et al, (2008) in traditional Spanish varieties of red fruits pepper $(1.79 \mathrm{~g} / 100 \mathrm{~g}$ of fruits DW). However, these were lower than the total fatty acid amount found in paprika varieties of Morocco (7.55 -8.67\%DM) found by Zaki et al, (2013).

The variation of total lipids amount of spicy fruits among sites $\left(1.20\left(\mathrm{Site}_{3}\right), 1.23\left(\mathrm{Site}_{1}\right)\right.$ and $1.42 \mathrm{~g} / 100 \mathrm{~g}$ of ripe fruits DW $\left.\left(\mathrm{Site}_{2}\right)\right)$ was in the same way as the variation of dark red color frequency which varied from $31.1 \%$ $\left(\mathrm{Site}_{3}\right), 44.6 \%\left(\mathrm{Site}_{1}\right)$ to $67.9 \%\left(\mathrm{Site}_{2}\right)$. This result suggests a relation between pigments dependent color and lipids content. Indeed, according to Matsufuji et al. (1998), capsanthin pigments accumulation in the pericarp of ripe fruit which is the major Carotenoid responsible of red pepper (30\% to $60 \%$ ), is a fat-soluble. 
Table 6. Total lipids and fatty acids composition of spicy fruits pepper from Maleh valley

\begin{tabular}{|c|c|c|c|c|c|c|c|c|c|}
\hline \multirow{2}{*}{ ANOVA } & \multirow{2}{*}{ Lipids } & \multicolumn{5}{|c|}{ Fatty acids } & \multirow{2}{*}{ USFA } & \multirow{2}{*}{ SFA } & \multirow{2}{*}{ SFA/USFA } \\
\hline & & Linoleic & Oleic & Palmitic & Myristic & Stearic & & & \\
\hline $\mathbf{B}_{1}$ & $1.15^{b}$ & $75.5^{\mathrm{a}}$ & $12.8^{\mathrm{a}}$ & $10.1^{\mathrm{a}}$ & $1.17^{\mathrm{bc}}$ & $0.38^{\mathrm{d}}$ & $88.3^{\mathrm{a}}$ & $11.7^{\mathrm{a}}$ & $0.13^{\mathrm{a}}$ \\
\hline $\mathbf{B}_{2}$ & $1.14^{\mathrm{b}}$ & $75.2^{\mathrm{a}}$ & $13.1^{\mathrm{a}}$ & $9.99^{\mathrm{a}}$ & $1.15^{\mathrm{c}}$ & $0.50^{\mathrm{b}}$ & $88.4^{\mathrm{a}}$ & $11.6^{\mathrm{a}}$ & $0.13^{\mathrm{a}}$ \\
\hline $\mathbf{B}_{3}$ & $1.46^{\mathrm{a}}$ & $75.6^{\mathrm{a}}$ & $12.9^{\mathrm{a}}$ & $9.76^{\mathrm{a}}$ & $1.24^{\mathrm{a}}$ & $0.54^{\mathrm{a}}$ & $88.5^{\mathrm{a}}$ & $11.5^{\mathrm{a}}$ & $0.13^{\mathrm{a}}$ \\
\hline $\mathbf{B}_{4}$ & $1.16^{\mathrm{b}}$ & $74.4^{\mathrm{a}}$ & $13.2^{\mathrm{a}}$ & $10.7^{\mathrm{a}}$ & $1.20^{\mathrm{ab}}$ & $0.43^{\mathrm{c}}$ & $87.7^{\mathrm{a}}$ & $12.3^{\mathrm{a}}$ & $0.14^{a}$ \\
\hline Site $_{1}$ & $1.23^{b}$ & $75.2^{\mathrm{a}}$ & $13.0^{\mathrm{c}}$ & $10.2^{\mathrm{c}}$ & $1.19^{\mathrm{a}}$ & $0.46^{c}$ & $88.2^{\mathrm{a}}$ & $11.8^{\mathrm{c}}$ & $0.13^{c}$ \\
\hline Site(Acc) & $* * *$ & NS & NS & NS & * & ** & NS & NS & NS \\
\hline F-value & 247.1 & 2.93 & 1.90 & 2.77 & 14.2 & 174.3 & 2.68 & 2.68 & 1.00 \\
\hline LSD & 0.04 & 1.34 & 0.54 & 1.07 & 0.04 & 0.02 & 1.04 & 1.04 & 0.02 \\
\hline
\end{tabular}

ANOVA significant $\mathrm{P}<0.05$, USFA: Unsatured fatty acids, SFA: Satured fatty acids

\begin{tabular}{|c|c|c|c|c|c|c|c|c|c|}
\hline \multirow{2}{*}{ ANOVA } & \multirow{2}{*}{ Lipids } & \multicolumn{5}{|c|}{ Fatty acids } & \multirow{2}{*}{ USFA } & \multirow{2}{*}{ SFA } & \multirow{2}{*}{ SFA/USFA } \\
\hline & & Linoleic & Oleic & Palmitic & Myristic & Stearic & & & \\
\hline $\mathrm{E}_{3}$ & $1.44^{\mathrm{b}}$ & $72.7^{\mathrm{bc}}$ & $13.7^{\mathrm{a}}$ & $11.7^{\mathrm{c}}$ & $1.09^{c}$ & $0.80^{\mathrm{a}}$ & $86.5^{c}$ & $13.5^{b}$ & $0.16^{\mathrm{b}}$ \\
\hline $\mathrm{E}_{4}$ & $1.46^{\mathrm{b}}$ & $71.3^{\mathrm{d}}$ & $14.1^{\mathrm{a}}$ & $13.0^{\mathrm{a}}$ & $1.06^{\mathrm{e}}$ & $0.66^{\mathrm{b}}$ & $85.3^{\mathrm{d}}$ & $14.7^{\mathrm{a}}$ & $0.17^{\mathrm{a}}$ \\
\hline $\mathrm{E}_{5}$ & $1.36^{\mathrm{c}}$ & $74.4^{\mathrm{a}}$ & $13.0^{c}$ & $10.8^{\mathrm{d}}$ & $1.11^{\mathrm{b}}$ & $0.64^{\mathrm{b}}$ & $87.5^{\mathrm{a}}$ & $12.5^{\mathrm{d}}$ & $0.15^{\mathrm{b}}$ \\
\hline $\mathrm{E}_{6}$ & $1.54^{\mathrm{a}}$ & $72.1^{\mathrm{c}}$ & $13.2^{\mathrm{bc}}$ & $12.9^{\mathrm{b}}$ & $1.12^{\mathrm{a}}$ & $0.76^{\mathrm{a}}$ & $85.2^{\mathrm{d}}$ & $14.7^{\mathrm{a}}$ & $0.18^{\mathrm{a}}$ \\
\hline $\mathrm{E}_{7}$ & $1.31^{\mathrm{c}}$ & $73.3^{\mathrm{b}}$ & $13.6^{\mathrm{ab}}$ & $11.4^{\mathrm{c}}$ & $1.07^{\mathrm{d}}$ & $0.67^{b}$ & $86.9^{\mathrm{b}}$ & $13.1^{c}$ & $0.15^{\mathrm{b}}$ \\
\hline Site $_{2}$ & $1.42^{\mathrm{a}}$ & $72.8^{c}$ & $13.5^{\mathrm{a}}$ & $11.9^{\mathrm{a}}$ & $1.09^{b}$ & $0.70^{\mathrm{a}}$ & $86.3^{c}$ & $13.7^{a}$ & $0.16^{\mathrm{a}}$ \\
\hline Site(Acc) & $* *$ & $* *$ & $*$ & $* * *$ & $* * *$ & $* *$ & $* * *$ & $* * *$ & $* *$ \\
\hline F-value & 16.8 & 36.7 & 8.07 & 131.4 & 75.7 & 19.8 & 190.6 & 190.6 & 19.1 \\
\hline LSD & 0.08 & 0.72 & 0.53 & 0.30 & 0.01 & 0.06 & 0.26 & 0.26 & 0.01 \\
\hline
\end{tabular}

ANOVA significant $\mathrm{P}<0.05$, USFA: Unsatured fatty acids, SFA: Satured fatty acids

\begin{tabular}{|c|c|c|c|c|c|c|c|c|c|}
\hline \multirow{2}{*}{ ANOVA } & \multirow{2}{*}{ Lipids } & \multicolumn{5}{|c|}{ Fatty acids } & \multirow{2}{*}{ USFA } & \multirow{2}{*}{ SFA } & \multirow{2}{*}{ SFA/USFA } \\
\hline & & Linoleic & Oleic & Palmitic & Myristic & Stearic & & & \\
\hline$M_{1}$ & $1.14^{\mathrm{c}}$ & $74.7^{\mathrm{a}}$ & $13.0^{c}$ & $10.7^{\mathrm{g}}$ & $1.03^{\mathrm{ab}}$ & $0.57^{\mathrm{bc}}$ & $87.7^{\mathrm{a}}$ & $12.3^{\mathrm{h}}$ & $0.14^{\mathrm{d}}$ \\
\hline $\mathrm{M}_{2}$ & $1.17^{\mathrm{c}}$ & $75.0^{\mathrm{a}}$ & $12.6^{\mathrm{d}}$ & $10.9^{f}$ & $0.94^{\mathrm{c}}$ & $0.55^{\mathrm{cd}}$ & $87.6^{b}$ & $12.4^{\mathrm{g}}$ & $0.14^{\mathrm{d}}$ \\
\hline $\mathrm{M}_{3}$ & $1.14^{\mathrm{c}}$ & $73.7^{c}$ & $13.6^{\mathrm{b}}$ & $11.1^{\mathrm{e}}$ & $1.05^{\mathrm{a}}$ & $0.59^{\mathrm{abc}}$ & $87.2^{\mathrm{d}}$ & $12.8^{\mathrm{e}}$ & $0.15^{\mathrm{cd}}$ \\
\hline $\mathrm{M}_{4}$ & $1.34^{\mathrm{a}}$ & $74.9^{\mathrm{a}}$ & $12.6^{d}$ & $10.9^{f}$ & $0.96^{\text {bc }}$ & $0.57^{c}$ & $87.5^{b}$ & $12.5^{\mathrm{g}}$ & $0.15^{\mathrm{cd}}$ \\
\hline$M_{5}$ & $1.11^{\mathrm{c}}$ & $71.3^{\mathrm{e}}$ & $14.2^{\mathrm{a}}$ & $12.9^{\mathrm{a}}$ & $1.04^{\mathrm{a}}$ & $0.51^{\mathrm{d}}$ & $85.5^{\mathrm{h}}$ & $14.5^{\mathrm{a}}$ & $0.17^{\mathrm{a}}$ \\
\hline $\mathrm{M}_{6}$ & $1.41^{\mathrm{a}}$ & $74.0^{\mathrm{bc}}$ & $12.9^{\text {cd }}$ & $11.5^{\mathrm{d}}$ & $1.03^{\mathrm{ab}}$ & $0.62^{\mathrm{ab}}$ & $86.9^{\mathrm{e}}$ & $13.1^{\mathrm{d}}$ & $0.15^{\text {bc }}$ \\
\hline $\mathrm{M}_{7}$ & $1.25^{\mathrm{b}}$ & $74.3^{b}$ & $13.1^{\mathrm{c}}$ & $11.0^{\mathrm{ef}}$ & $1.06^{\mathrm{a}}$ & $0.57^{c}$ & $87.4^{\mathrm{c}}$ & $12.6^{\mathrm{f}}$ & $0.15^{\mathrm{cd}}$ \\
\hline $\mathrm{M}_{8}$ & $1.13^{c}$ & $72.5^{\mathrm{d}}$ & $13.6^{\mathrm{b}}$ & $12.4^{\mathrm{b}}$ & $0.95^{\mathrm{c}}$ & $0.63^{\mathrm{a}}$ & $86.1^{\mathrm{g}}$ & $13.9^{\mathrm{b}}$ & $0.17^{\mathrm{a}}$ \\
\hline $\mathrm{M}_{9}$ & $1.16^{\mathrm{c}}$ & $72.5^{\mathrm{d}}$ & $14.0^{\mathrm{a}}$ & $11.95^{c}$ & $1.07^{\mathrm{a}}$ & $0.54^{\text {cd }}$ & $86.4^{\text {f }}$ & $13.6^{c}$ & $0.16^{\mathrm{b}}$ \\
\hline $\mathrm{Site}_{3}$ & $1.20^{\mathrm{b}}$ & $73.6^{\mathrm{b}}$ & $13.3^{\mathrm{b}}$ & $11.5^{b}$ & $1.01^{\mathrm{c}}$ & $0.57^{\mathrm{b}}$ & $86.9^{\mathrm{b}}$ & $13.1^{\mathrm{b}}$ & $0.15^{b}$ \\
\hline Site(Acc) & $* * *$ & $* * *$ & $* * *$ & $* * *$ & ** & $* *$ & $* * *$ & $* * *$ & $* * *$ \\
\hline F-value & 21.3 & 105.3 & 23.9 & 397.2 & 9.72 & 6.56 & 628.3 & 628.3 & 15.9 \\
\hline LSD & 0.07 & 0.39 & 0.36 & 0.12 & 0.07 & 0.05 & 0.10 & 0.10 & 0.09 \\
\hline
\end{tabular}

ANOVA significant $\mathrm{P}<0.05$, USFA: Unsatured fatty acids, SFA: Satured fatty acids

\begin{tabular}{|c|c|c|c|c|c|c|c|c|c|}
\hline \multirow{2}{*}{ ANOVA } & \multirow{2}{*}{ Lipids } & \multicolumn{5}{|c|}{ Fatty acids } & \multirow{2}{*}{ USFA } & \multirow{2}{*}{ SFA } & \multirow{2}{*}{ SFA/USFA } \\
\hline & & Linoleic & Oleic & Palmitic & Myristic & Stearic & & & \\
\hline Acc. & $* * *$ & $* * *$ & $* * *$ & $* * *$ & $* * *$ & $* * *$ & $* * *$ & $* * *$ & $* * *$ \\
\hline Site & $* * *$ & $* * *$ & $* * *$ & $* * *$ & $* * *$ & $* * *$ & $* * *$ & $* * *$ & $* * *$ \\
\hline Mean & $1.27 \pm 0.02$ & $73.7 \pm 0.23$ & $13.3 \pm 0.08$ & $11.3 \pm 0.16$ & $1.07 \pm 0.02$ & $0.58 \pm 0.02$ & $87.0 \pm 0.17$ & $13.0 \pm 0.17$ & $0.15 \pm 0.002$ \\
\hline Range & $1.10-1.55$ & $71.1-75.9$ & $12.5-14.3$ & $9.63-13.1$ & $0.89-1.25$ & $0.36-0.82$ & $85.0-88.6$ & $11.4-15.0$ & $0.13-0.18$ \\
\hline F-value & 46.6 & 62.0 & 17.6 & 76.8 & 14.2 & 63.9 & 92.0 & 92.0 & 20.0 \\
\hline LSD & 0.03 & 0.23 & 0.15 & 0.14 & 0.03 & 0.02 & 0.13 & 0.13 & 0.004 \\
\hline
\end{tabular}

ANOVA significant $\mathrm{P}<0.05$, USFA: Unsatured fatty acids, SFA: Satured fatty acids 
The fatty acids composition of spicy pepper fruits pericarp is listed in table 6 . A total of five fatty acids mostly abundant in the fruit pericarp of pepper were identified based on number of carbons as palmitic acid (16:0), stearic acid (17:0), myristic acid (14:0), oleic acid (18:1n-9) and linoleic acid (18:2n-6). The most abundant fatty acid was linoleic acid, oleic acid and palmitic acid regarding their parts of total fatty acid respectively $74 \%, 13.3 \%$ and $11.3 \%$. Linoleic acid is found in high concentration of unsaturated fatty acid with amount ranged from 0.786 to $1.112 \mathrm{~g}$ per $100 \mathrm{~g}$ of fruit pericarp DM, while, Palmitic acid was the main saturated fatty acid representing an average of 0.111 $\mathrm{g} / 100 \mathrm{~g}$ of fruit pericarp DM (Table 6). The others saturated fatty acids were detected in small quantities. The ratios of unsatured fatty acid (UFA)/ satured fatty acid (SFA) (6.76) were high due to the high amounts of unsaturated acids (87.03\%), particularly linoleic acid (73.73\%)(Table 6). Lipids of spicy pepper fruits produced in Maleh valley were rich especially in $\omega-6$ (linoleic acid) which human body is unable to produce (Simopoulos 2008). The ratio of linoleic acid $(\omega-6) /$ oleic acid $(\omega-3)$ was ranging among accessions from $4.98\left(\mathrm{M}_{5}\right)-6.00\left(\mathrm{M}_{4}\right)$. Considering the high ratio of $\omega-6 / \omega-3$, fruits pepper of Maleh valley are considered healthy beneficial and highly appropriate in human diet especially because they contribute to fat body and total cholesterol reduction (Simopoulos, 2010), in addition of preventing inflammatory processes and diseases as reported by Simopoulos, (2002) study. Moreover, $\omega-3$ even in lower content than that one of $\omega-6$, can exert protective effects against inflammatory and tumoral events once incorporated into the cells (Alexander, 1998; Gladine et al, 2012; Rose and Connolly, 1999).

\subsubsection{Total Phenols}

The mean value of total phenols (TPH) content found of Maleh spicy pepper fresh fruits was $73.28 \mathrm{mg}$ (GAE)/100g. Results showed significant variation among sites (51.5 $\left(\right.$ Site $\left._{1}\right)$ - $\left.90.1 \mathrm{mg}(\mathrm{GAE}) / 100 \mathrm{~g}\right) \quad\left(\mathrm{Site}_{3}\right)$ and among accessions (45.5 ( $\mathrm{E}_{4}$ and $\left.\mathrm{M}_{4}\right)$ - $\left.223.5 \mathrm{mg}(\mathrm{GAE}) / 100 \mathrm{~g}\right)\left(\mathrm{M}_{1}\right)$ (Table 7). Phenol compounds are found in high quantities in many accessions such as $\mathrm{M}_{1}(223.5 \mathrm{mg}(\mathrm{GAE}) / 100 \mathrm{~g})$, $\mathrm{M}_{5}(167.5 \mathrm{mg} \mathrm{GAE} / 100 \mathrm{~g})$ and $\mathrm{M}_{8}(113.0 \mathrm{mg}(\mathrm{GAE}) / 100 \mathrm{~g})$ from $\mathrm{Site}_{3}$. Our findings are in accordance with the results found in red pepper fresh fruits $(907-1700 \mu \mathrm{g}(\mathrm{GAE}) / \mathrm{g})$ by Gougoulias et al, (2017); or those reported for sweet red pepper (128 - $202.6 \mathrm{mg}(\mathrm{GAE}) / 100 \mathrm{~g})$ by Rodica Soare, (2017); or the results of some morphotypes of pepper (113.2 - $262.9 \mathrm{mg}(\mathrm{GAE}) / 100 \mathrm{~g}$ fresh weight) reported by Araceli Minerva et al, (2011); or those of Zimmer et al, (2012) found in pepper fruits of Capsicum baccatum $(149.28$ - $187.51 \mathrm{mg}(\mathrm{GAE}) / \mathrm{gDM}$; and were also in accordance with the average values $9.95-10.54 \mathrm{mg}$ (GAE)/g of fresh fruits reported by Chávez-Mendoza et al, (2013). The differences in the accumulation of polyphenols revealed among accessions suggested genetic factor. In addition of the genetic factor dependence on total phenol content in red pepper fruits, Chávez-Mendoza et al, (2013) study attributed the amount of TPH also to the types of peppers and the stages of fruits maturity, whereas, Bhandari et al, (2013) study assigned TPH amount to the growing condition effect. TPH are synthesized by plants as a response of stressed growing conditions (Howard et al. (2000) and Gougoulias et al, (2017)). Phenolic compounds constitute a part of human diet as they are found in many consumed fruits and vegetables (Chávez-Mendoza et al, 2013). Rodica Soare et al, (2017) study reported a high and significant correlation between TPH and antioxidant activity (0.745) underlying therefore their health beneficial properties in agreement with Howard et al. (2000). Thus, spicy fruits of Maleh valley might provide an excellent source of health-related compounds inducing protective mechanisms against free radicals. In addition, the antioxidants functions promote the energy metabolism and the suppression of fat accumulation.

Table 7. Carbohydrates, total phenols and fruits pungency components of Maleh valley hot pepper

\begin{tabular}{|c|c|c|c|c|c|c|c|c|}
\hline ANOVA & DM & Carb & TP & CAD & CAP & DHC & CAP/DHC & SHU \\
\hline $\mathbf{B}_{1}$ & $10.8^{\mathrm{a}}$ & $56.6^{\mathrm{b}}$ & $0.067^{\mathrm{ab}}$ & $1870.9^{\mathrm{d}}$ & $1178.2^{\mathrm{c}}$ & $692.8^{d}$ & $1.70^{\mathrm{b}}$ & $30122^{c}$ \\
\hline $\mathbf{B}_{2}$ & $11.4^{\mathrm{a}}$ & $39.1^{\mathrm{c}}$ & $0.049^{b}$ & $2026.1^{\mathrm{b}}$ & $1330.9^{\mathrm{b}}$ & $695.2^{\mathrm{c}}$ & $1.91^{\mathrm{a}}$ & $32620^{\mathrm{b}}$ \\
\hline $\mathbf{B}_{3}$ & $11.6^{\mathrm{a}}$ & $40.3^{c}$ & $0.050^{\mathrm{b}}$ & $1974.8^{\mathrm{bc}}$ & $1246.9^{\mathrm{bc}}$ & $728.0^{\mathrm{b}}$ & $1.71^{\mathrm{b}}$ & $31795^{\text {bc }}$ \\
\hline $\mathbf{B}_{4}$ & $11.6^{\mathrm{a}}$ & $61.9^{\mathrm{a}}$ & $0.086^{\mathrm{a}}$ & $2305.9^{\mathrm{a}}$ & $1498.4^{\mathrm{a}}$ & $807.5^{\mathrm{a}}$ & $1.86^{\mathrm{ab}}$ & $37126^{\mathrm{a}}$ \\
\hline Site $_{1}$ & $11.3^{\mathrm{a}} \pm 0.14$ & $49.5^{b} \pm 3.8$ & $0.063^{b} \pm 0.006$ & $2044.5^{b} \pm 62.3$ & $1313.6^{c} \pm 47.2$ & $730.9^{b} \pm 17.5$ & $1.80^{b} \pm 0.04$ & $32916^{b} \pm 1003.0$ \\
\hline Site(Acc.) & NS & $* *$ & NS & $* *$ & $*$ & $* * *$ & NS & $* *$ \\
\hline F-value & 3.03 & 95.8 & 4.86 & 31.9 & 17.9 & - & 5.91 & 31.9 \\
\hline LSD & 0.87 & 4.59 & 0.03 & 129.9 & 129.9 & 0.00 & 0.182 & 2091.8 \\
\hline
\end{tabular}




\begin{tabular}{|c|c|c|c|c|c|c|c|c|}
\hline ANOVA & DM & Carb & TP & CAD & CAP & DHC & CAP/DHC & SHU \\
\hline $\mathbf{E}_{3}$ & $10.4^{\mathrm{b}}$ & $55.4^{\mathrm{a}}$ & $0.048^{\mathrm{a}}$ & $2595.3^{b}$ & $1650.6^{\mathrm{b}}$ & $944.7^{\mathrm{a}}$ & $1.75 b^{c}$ & $41784^{b}$ \\
\hline $\mathbf{E}_{4}$ & $11.6^{\mathrm{a}}$ & $39.8^{\mathrm{b}}$ & $0.046^{\mathrm{a}}$ & $2305.1^{\mathrm{c}}$ & $1441.2^{\mathrm{c}}$ & $865.0^{\mathrm{b}}$ & $1.67^{\mathrm{c}}$ & $37113^{c}$ \\
\hline $\mathbf{E}_{5}$ & $11.5^{\mathrm{a}}$ & $37.6^{\mathrm{b}}$ & $0.052^{\mathrm{a}}$ & $1871.3^{\mathrm{e}}$ & $1203.4^{\mathrm{d}}$ & $667.8^{\mathrm{d}}$ & $1.80^{\mathrm{b}}$ & $30127^{e}$ \\
\hline $\mathbf{E}_{6}$ & $11.6^{\mathrm{a}}$ & $37.5^{\mathrm{b}}$ & $0.047^{\mathrm{a}}$ & $2781.4^{\mathrm{a}}$ & $1804.1^{\mathrm{a}}$ & $977.3^{\mathrm{a}}$ & $1.85^{\mathrm{ab}}$ & $44781^{\mathrm{a}}$ \\
\hline $\mathbf{E}_{7}$ & $10.4^{\mathrm{b}}$ & $38.8^{\mathrm{b}}$ & $0.066^{\mathrm{a}}$ & $2071.1^{d}$ & $1363.0^{\mathrm{c}}$ & $708.1^{\mathrm{c}}$ & $1.93^{\mathrm{a}}$ & $33344^{\mathrm{d}}$ \\
\hline Site $_{2}$ & $11.1^{b} \pm 0.20$ & $41.8^{c} \pm 2.3$ & $0.052^{c} \pm 0.003$ & $2324.8^{\mathrm{a}} \pm 111.5$ & $1492.3^{\mathrm{a}} \pm 71.5$ & $832.6^{a} \pm 41.5$ & $1.80^{b} \pm 0.03$ & $37430^{\mathrm{a}} \pm 1795.2$ \\
\hline Site(Acc) & $*$ & $* *$ & NS & $* * *$ & $* *$ & $* * *$ & * & $* * *$ \\
\hline F-value & 8.13 & 34.3 & 1.34 & 61.2 & 37.3 & 196.8 & 7.76 & 61.2 \\
\hline LSD & 0.78 & 4.61 & 0.03 & 166.8 & 136.5 & 34.8 & 0.12 & 2685.6 \\
\hline ANOVA & $\mathbf{D M}$ & Carb & TP & CAD & CAP & DHC & CAP/DHC & SHU \\
\hline $\mathbf{M}_{1}$ & $11.5^{\mathrm{a}}$ & $42.0^{d}$ & $0.224^{\mathrm{a}}$ & $2669.9^{\mathrm{a}}$ & $1730.8^{\mathrm{a}}$ & $939.1^{\mathrm{a}}$ & $1.85^{\mathrm{abc}}$ & $42985^{\mathrm{a}}$ \\
\hline $\mathbf{M}_{2}$ & $10.6^{\mathrm{bc}}$ & $66.0^{\mathrm{ab}}$ & $0.050^{\mathrm{d}}$ & $1711.2^{\mathrm{e}}$ & $1102.9^{\mathrm{e}}$ & $608.3^{\mathrm{e}}$ & $1.81^{\mathrm{bc}}$ & $27551^{\mathrm{e}}$ \\
\hline $\mathbf{M}_{3}$ & $10.4^{\mathrm{c}}$ & $56.5^{c}$ & $0.047^{\mathrm{d}}$ & $1963.5^{\text {de }}$ & $1266.7^{\mathrm{de}}$ & $696.79^{\text {cde }}$ & $1.82^{\mathrm{bc}}$ & $31612^{\mathrm{de}}$ \\
\hline $\mathbf{M}_{4}$ & $10.3^{c}$ & $64.5^{\mathrm{ab}}$ & $0.046^{\mathrm{d}}$ & $2048.9^{\mathrm{cd}}$ & $1304.6^{d}$ & $744.3^{\mathrm{cd}}$ & $1.75^{\mathrm{c}}$ & $32987^{\mathrm{cd}}$ \\
\hline $\mathbf{M}_{5}$ & $10.3^{c}$ & $66.0^{\mathrm{ab}}$ & $0.168^{b}$ & $2026.0^{\text {cd }}$ & $1340.1^{\text {cd }}$ & $685.9^{\text {cde }}$ & $1.96^{\mathrm{a}}$ & $32618^{\mathrm{cd}}$ \\
\hline $\mathbf{M}_{6}$ & $11.1^{\mathrm{ab}}$ & $60.2^{\mathrm{bc}}$ & $0.052^{\mathrm{d}}$ & $2289.3^{\mathrm{bc}}$ & $1503.8^{\mathrm{bc}}$ & $785.5^{\mathrm{bc}}$ & $1.92^{\mathrm{ab}}$ & $36857^{\mathrm{bc}}$ \\
\hline $\mathbf{M}_{7}$ & $11.0^{\mathrm{ab}}$ & $61.9^{\mathrm{abc}}$ & $0.061^{\mathrm{d}}$ & $1905.4^{\mathrm{de}}$ & $1227.1^{\mathrm{de}}$ & $678.3^{\text {de }}$ & $1.81^{b c}$ & $30677^{\mathrm{de}}$ \\
\hline $\mathbf{M}_{8}$ & $10.2^{\mathrm{c}}$ & $67.4^{\mathrm{a}}$ & $0.113^{\mathrm{c}}$ & $1981.8^{\text {de }}$ & $1304.0^{\mathrm{d}}$ & $677.8^{\mathrm{de}}$ & $1.93^{\mathrm{ab}}$ & $31907^{\text {de }}$ \\
\hline $\mathbf{M}_{9}$ & $11.4^{\mathrm{a}}$ & $66.1^{\mathrm{ab}}$ & $0.051^{\mathrm{d}}$ & $2509.2^{\mathrm{ab}}$ & $1632.5^{\mathrm{ab}}$ & $876.7^{\mathrm{ab}}$ & $1.86^{\mathrm{abc}}$ & $40398^{\mathrm{ab}}$ \\
\hline Site $_{3}$ & $10.7^{c} \pm 0.12$ & $61.2^{a} \pm 1.87$ & $0.090^{a} \pm 0.015$ & \begin{tabular}{l|l}
5 & $2122.8^{b} \pm 73.0$
\end{tabular} & $1379.2^{b} \pm 48.2$ & $743.6^{b} \pm 25.4$ & \begin{tabular}{l|l}
4 & $1.86^{\mathrm{a}} \pm 0.02$
\end{tabular} & \begin{tabular}{l|l}
$24177^{b} \pm 1175$ \\
\end{tabular} \\
\hline Site(Acc) & $* *$ & $* * *$ & $* * *$ & $* * *$ & $* * *$ & $* *$ & NS & $* * *$ \\
\hline F-value & 8.00 & 17.1 & 69.2 & 10.8 & 10.8 & 9.40 & 2.61 & 10.8 \\
\hline LSD & 0.53 & 5.95 & 0.02 & 286.7 & 189.3 & 106.5 & 0.13 & 4615.3 \\
\hline ANOVA & DM & Carb & TP & CAD & CAP & DHC & CAP/DHC & SHU \\
\hline Acc. & $* * *$ & $* * *$ & $* * *$ & $* * *$ & $* * *$ & $* * *$ & $* * *$ & $* * *$ \\
\hline Site(Acc.) & $* * *$ & $* * *$ & $* * *$ & $* * *$ & $* * *$ & $* * *$ & $*$ & $* * *$ \\
\hline Mean & $10.9 \pm 0.1$ & $53.2 \pm 2.0$ & $0.073 \pm 0.008$ & $2161.5 \pm 51.7$ & $1396.0 \pm 33.9$ & $765.5 \pm 18.5$ & $1.83 \pm 0.02$ & $34800.3 \pm 832.5$ \\
\hline Range & $10.1-11.8$ & $36.6-67.5$ & \begin{tabular}{l|l}
$0.040-0.226$ & 1 \\
\end{tabular} & $1674.0-2819.1$ & $1075.8-1837.4$ & 598.2-981.8 & $1.63-1.97$ & $26951.4-45388.0$ \\
\hline F-value & 9.74 & 63.1 & 47.3 & 20.7 & 18.2 & 22.1 & 5.12 & 20.7 \\
\hline LSD & 0.22 & 1.88 & 0.01 & 84.8 & 59.1 & 29.5 & 0.05 & 1364.8 \\
\hline
\end{tabular}

DM: Dry Matter, Carb: carbohydrates, TP: Total Phenols ( $\mu \mathrm{g}$ GAE/100g), CAD: Capsaicinoïds, CAP: Capsaicin, DHC: dihydrocapsaicin, SHU: Heat Scoville Unit, LSD: Least Significant Difference

\subsubsection{Capsaicinoids}

The average of capsaicinoids concentration in dried pericarp of Maleh hot pepper was $2.16 \mathrm{mg} / \mathrm{g}$ varying among sites from $2.04\left(\mathrm{Site}_{1}\right)$ to $2.32\left(\mathrm{Site}_{2}\right) \mathrm{mg} / \mathrm{g}$ and among accessions from $1.67\left(\mathrm{M}_{8}\right)$ to $2.82\left(\mathrm{E}_{6}\right) \mathrm{mg} / \mathrm{g}$ (Table 7). These results underline the genetic control on Capsaicinoids synthesis in agreement with Stewards et al, (2005) study. These values were higher than those found for Kalaa des Sraghna paprika $(0.185 \mathrm{mg} / \mathrm{g})$, Gharb paprika $(0.119 \mathrm{mg} / \mathrm{g})$, and Tadla paprika $(0.066 \mathrm{mg} / \mathrm{g})$ (Zaki et al, 2013). Capsaicin and dihydrocapsaicin are the main indicators for the pungency level measured in Scoville Heat Unit (SHU) (Topuz \& Ozdemir, 2007). Fruits pungency is among the primary quality criteria that determines commercial value. This flavor is proportional to the level of Capsaicinoids compounds concentrated in fruit pericarp and placenta (Howard and Wildman, 2007). Capsaicin was found to be the major component of the total capsaicinoids with $64.6 \%$ in ripped fruit in agreement with the finding (69\%) of Fattorusso et al, (2008) and of De Witt, 1999 and higher than the finding of Zaki et al. (2013) 53\% and 51\% respectively for Kalaa des Sraghna and Gharb pepper cultivars. Capsaicin content ranged among accessions between $1.08\left(\mathrm{M}_{2}\right)-1.84\left(\mathrm{E}_{6}\right) \mathrm{mg} / \mathrm{g}$ DM with an average of $1.40 \mathrm{mg} / \mathrm{g}$ DM (Table 7). The average ratio of capsaicin/dihydrocapsaicin was 1.83 and was similar to one of Gharb pepper cultivar (1.82) and close to one of ElKalaa des Sraghna (1.97) pepper cultivar according to Zaki et al. (2013) study and lower than the ratio (2:1) findings in all of González-Zamora et al. (2013); Manirakiza et al. (2003) and Garcés-Claver et al. (2006) studies.

The proportions of capsaicinoids and dihydrocapsaicin were significantly and positively correlated with lipids content $\left(0.330^{*}\right)$ and $\left(0.414^{*}\right)$ respectively. Whereas, percentage of capsaicin was significantly and negatively 
correlated with lipids $\left(-0.385^{*}\right)$. This result suggests that lipids might be involved in Capsainoids production. Indeed, Wahyuni et al, (2013) reported that fatty acids have a great metabolic and structural importance in their contribution to capsaicinoids components synthesis. Thus, this finding might argue the lower amount of lipids in spicy pepper of Maleh valley than those of sweet pepper varieties of Morocco (Zaki et al, 2013).

\subsubsection{Fruits Pungency}

The average of pungency strength measured in SHU was 34800.3 varying among sites from $32915.9\left(\right.$ Site $\left._{1}\right)$ to $37429.7\left(\right.$ Site $\left._{2}\right)$ and among accessions from $27550.5\left(\mathrm{M}_{2}\right)$ to $44780.7\left(\mathrm{E}_{6}\right)$ as listed in table 7 . Pepper fruits of Maleh valley pungency might be categorized, according to the commonly accepted Scoville organoleptic test, into hot pungency group (Weiss et al, 2002) or into highly pungent group (Eich et al, 2008). In addition, pungency strength significant variation among accessions and sites might be attributed in addition of genetic factor (Stewards et al, 2005), to salt concentration differences in irrigated water and to farmers' selection impact. The highest level of pungency was found mainly among accessions of $\mathrm{Site}_{2}$ as $\mathrm{E}_{6}(44780.7 \mathrm{SHU})$ and $\mathrm{E}_{3}(41783.8 \mathrm{SHU})$ where salt concentration of irrigated water was the highest (3.74) g/l and in $\mathrm{M}_{1}$ accession (42984.85 SHU) and $\mathrm{M}_{9}$ (40397.95 $\mathrm{SHU}$ ) of $\mathrm{Site}_{3}$ (Table 7). Taking in account the same sampling fruits growth maturity, the finding results support the interaction of plant genotype $\mathrm{x}$ environment salty constraints on Capsaicinoids biosynthesis and the abundance of their relative components in accordance with Howard et al. (2000) and Zewdie and Bosland, (2000). The accumulations of these metabolites started in response of water deficiency to maintain osmotic potential balance ((Zhu, 2002); Zhani et al, (2013)). Genotypes adaptability of hot pepper in salty environment was related therefore to plant osmotic adjustment potential that usually established by intake of inorganic ions as well as the abundance of Capsaicinoids components accumulation (Gangadhar et al, 2012).

In addition, significant correlation was observed between pungency strength (SHU) and either total fatty acids content $(+0.331 *)$ and unsatured fatty acids percentage $(-0.431 * *)$ mainly with linoleic acid $\left(-0.405^{*}\right)$. In this context, previous studies reported that pungent spices increase the unsaturated fatty acids catabolism allowing human protection either against risks of hypercholesterolemia (Lee et al, 2011) and obesity (Martel et al, 2017), or atherosclerotic cardiovascular diseases (Sharma et al, 2013) or diabetes type 2 ( Qin et al, 2012).

\subsection{Hierarchical Cluster of Metabolites Components}

Hierarchical analysis based on minimum spanning tree complete link revealed a similarity of ripped fruits metabolite components ranging from 30 to $98 \%$ underlining a high variability of nutritional value and pungency among accessions (Figure 4). Six clusters were identified at $87 \%$ of similarity. Three clusters of them grouped major accessions. The first cluster was the largest one containing $50 \%$ of analyzed accessions. The second and the third grouped each one three accessions from two different sites supporting seed exchange network between sites. The three others clusters grouped each one a single accession respectively $\mathrm{E}_{6}, \mathrm{M}_{1}$ and $\mathrm{M}_{9}$. These accessions are distinguished by their high fruit pungency according to heat Scoville unit (44781, 42985 and 40398 respectively).

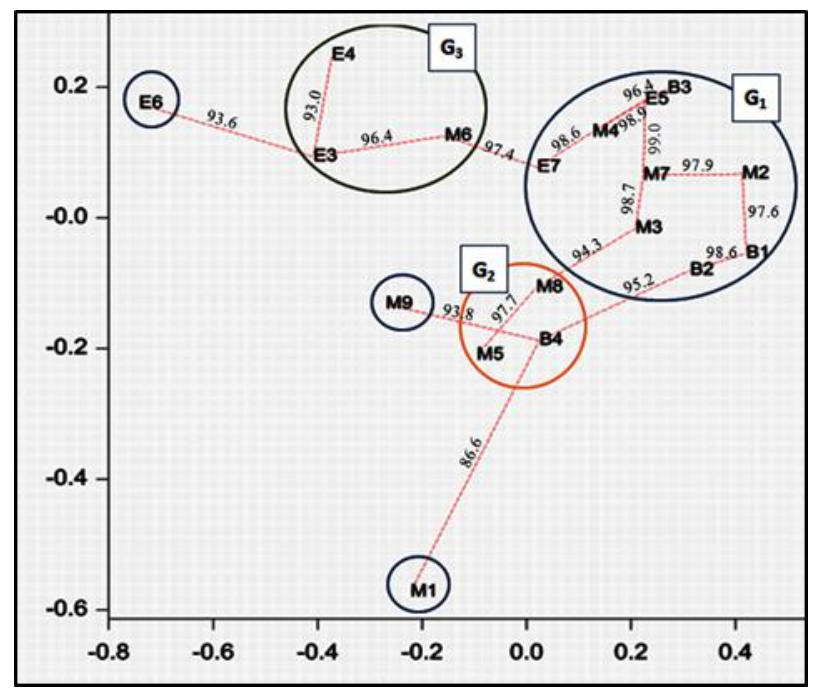

Figure 4. Hierarchical clustering based on similarity of fruits metabolite components content

\section{Conclusions}

Fruits of spicy pepper are among the most important vegetables and spices widely used for food as a colorant and as a tasty spice with flavor characteristic. In addition, pepper fruits are an effective source of bioactive components with antioxidants properties. Our study evidenced a great genetic variability among hot pepper meta-population of Maleh valley on the basis of several fruit phenotypic traits and biochemical composition. Fruits shape, bright attractive red color and pungent taste strength are the primarily spicy fruits valuable qualitative traits. Indeed, the intensity of red color and degree of pungency are the main factors determining fruits quality and market price. This variability might be attributed to plant response in salty stress condition throughout plant growth, fruit feature and fruits chemical quality. Fruits pungency strength was related to the concentration of capsaicinoids components in ripped fruits of pepper which varied among accessions and was promoted by salty stress and farmers' cultural practices.

Our finding revealed that spicy pepper fruits of Maleh valley have high nutritional value. Their intake are associated with low calorie value, low amount of total 
lipids composed mainly with unsatured fatty acids, high and variable phenols contents with antioxidant activity. Furthermore, the high ratio of $\omega-6 / \omega-3$ is considered as healthy beneficial and highly appropriate in human diet.

Based on the finding results, the most divergent accessions based on phenotypic qualitative characters were $\mathrm{E}_{4}, \mathrm{E}_{5}$ and $\mathrm{E}_{6}$ from Site $; \mathrm{B}_{1}, \mathrm{~B}_{2}, \mathrm{~B}_{3}$ and $\mathrm{B}_{4}$ from Site ${ }_{1}$ and $\mathrm{M}_{6}$ and $\mathrm{M}_{8}$ from Site $_{3}$. The wide genetic diversity among individual genotypes of these accessions could be related to large field size, high rates of cross pollination events as open pollination could reach $90 \%$ as reported in previous studies, add to strong seed exchange and low farmers' selection impact.

In addition, the most spicy fruit taste was found in $\mathrm{E}_{3}, \mathrm{E}_{6}$, $\mathrm{M}_{1}$ and $\mathrm{M}_{9}$ accessions. Furthermore, $\mathrm{E}_{6}$ was qualified with high nutritive value. This accession represents a valuable source of promising genotypes in terms of phenotypic and nutritional quality, which might be applied for hot pepper crop genetic improvement.

Thus, our findings might be useful in supervising farmers' plant selection to increase fruits trade value of spicy pepper landrace of Maleh valley. Otherwise, the importance of this genetic base as source of potential genotypes of interest leads the Moroccan agricultural policy to strengthen its on-farm conservation through fruits valorization under geographical indication (IGP) since April 2018

\section{REFERENCES}

[1] Aggarwal, B.B, and Shishodia, S. (2006). Molecular targets of dietary agents for prevention and therapy of cancer. Biochemical pharmacology. 71(10):1397-1421.

[2] Aggarwal, B.B, Van Kuiken, M.E, Iyer L.H, Harikumar, K.B, Sung, B. (2009). Molecular targets of nutraceuticals derived from dietary spices: potential role in suppression of inflammation and tumorigenesis. Experimental biology and medicine. 234(8):825-849.

[3] Alexander, J.W. (1998). Immuno-nutrition: The role of $\omega-3$ fatty acids. Nutrition. 14(7-8): 627-633.

[4] Alvarez-Parrilla, E., De la Rosa, L.A, Amarowicz, R. and Shahidi, F. (2011). Antioxidant activity of fresh and processed Jalapeño and Serrano peppers. Journal of Agricultural and Food Chemistry. 59: 163-173.

[5] Antonious, G.F, Kochhar, T.S, Jarret, R.L. and Snyder, J.C. (2006). Antioxidants in hot pepper: Variation among accessions. Journal of Environmental Science and Health, part B. 41: 1237-1243.

[6] Araceli Minerva, V.G, Chávez-Servia, J.L, Carrillo Rodríguez, J.C, and López, Mercedes G. (2011). Phytochemical Evaluation of Wild and Cultivated Pepper (Capsicum annuum L. and C. pubescens Ruiz \& Pav.) From Oaxaca, Mexico. Chilean Journal Of Agricultural Research, 71(4): 578-585.
[7] Bernardo, A., Martınez, S., Alvarez, M., Fernandez, A. and Lopez, M. (2008). The composition of two Spanish pepper varieties (Fresno de la Vega and Benavente-los Valles) in different ripening stages. Journal of Food Quality. 31: 701-716.

[8] Bhandari, S.R., Jung, B.D, Baek, H.Y. and Lee, Y.S. (2013). Ripening-dependent Changes in Phyto-nutrients and Antioxidant Activity of Red Pepper (Capsicum annuum L.) Fruits Cultivated under Open-field Conditions. Hortscience. 48(10):1275-1282.

[9] Bozokalfa, M.K., Eşiyok, D. and Turhan, K. (2009). Patterns of phenotypic variation in a germplasm collection of pepper (Capsicum annuum L.) from Turkey. Spanish Journal of Agricultural Research. 7(1): 83-95

[10] Buczkowska, H., Dyduch J., Agnieszka N. (2013). Capsicinoids in hot pepper depending on fruit maturity stage and harvest date. Acta Sci. Pol., Hortorum Cultus. 12(6): 183-196

[11] Chávez-Mendoza, C., Sánchez, E., Carvajal-Millán, E., Muñoz-Márquez, E. and Guevara-Aguilar, A. (2013). Characterization of the Nutraceutical Quality and Antioxidant Activity in Bell Pepper in Response to Grafting. Molecules. 18: 15689-15703.

[12] Collins, M.D., Wasmund, L.M, and Bosland, P.W. (1995). Improved method for quantifying capsaicinoids in Capsicum using high performance liquid chromatography. Horticultural Science. 30: 137-139.

[13] De Witt D. (1999). The nature of capsaicin, The Chile Pepper Encyclopedia. Harper Collins Publishers, New York.

[14] Deepa, N., Kaur, C., George, B., Singh, B., and Kapoor, H.C. (2007). Antioxidant constituents in some sweet pepper (Capsicum annuum L.). LWT-Food Science and Technology. 40: 212-219.

[15] Djamgoz, M.B.A, and Isbilen, B. (2006). Dietary compounds as anti-cancer agents: A preliminary evaluation of ion channels and membrane excitability as possible target mechanisms. Turkish Journal of Biochemistry. 31: 57-68.

[16] Dong, M.W. (2000). How hot is that pepper? Quantifying capsaicinoids with chromatography. Today's Chemist at Work. 9: 17-20.

[17] Eich, E. (2008). Solanaceae and Convolvulaceae: Secondary Metabolites. Springer (Germany), 282-292.

[18] El Ouali, A. (1997). Etude paysagère de l'embouchure de l'oued El Maleh et proposition d'aménagement. Thèse 3ème cycle. Institut Agronomique et vétérinaire Hassan II. Rabat-Maroc. 111p.

[19] Estrada, B., Bernal, M.A., Diaz, J., Pomar, F., and Merino, F. (2000). Fruit development in Capsicum annuum: Changes in capsaicin, lignin, free phenolics and peroxidase patterns. Journal of Agricultural and Food Chemistry. 48: 6234 6239.

[20] Fattorusso, E., Taglialatela-Scafati, O. (2008). Modern alkaloids: structure, isolation, synthesis and biology, Wiley, Weinheim: 73-104.

[21] Gangadhar B.H., et al. (2012). Comparative study of color, pungency, and biochemical composition in chili pepper 
(Capsicum annuum) under different light-emitting diode treatments. HortScience. 47(12): 1729-1735.

[22] Garcés-Claver, A., Arnedo-Andrés, M.S., Abadía, J., Gil-Ortega R., and Alvarez-Fernández, A. (2006). Determination of capsaicin and dihydrocapsaicin in Capsicum fruits by liquid chromatographyelectrospray/tim e of flight mass spectrometry. Journal of Agricultural and Food Chemistry. 54: 9303-9311.

[23] Gladine, C., et al. (2012). Increasing intake of long chain omega 3 PUFA enhances lipoperoxidation and modulates hepatic gene expression in a dose-dependent manner. British Journal of Nutrition. 107(9):1254- 1273.

[24] González-Zamora, A., Sierra-Campos, E., Luna-Ortega, J.G., Pérez-Morales, R., Ortiz, J.C.R., and García-Hernández, J.L. (2013). Characterization of different capsicum varieties by evaluation of their capsaicinoids content by high performance liquid chromatography, determination of pungency and effect of high temperature. Molecules.18: 13471-13486.

[25] Gougoulias, N., Wogiatzi, E., Vagelas, I., Giurgiulescu, L., Gogou, I., Ntalla, M.N., Kalfountzos, D. (2017). Comparative study on polyphenols content, capsaicin and antioxidant activity of different hot peppers varieties (Capsicum annuum L.) under environmental conditions of Thessaly region, Greece. Carpathian Journal of food science and Technology. 9(1): 109-116.

[26] Guinoza, A.A., Siraichi, J.G., Gazim, Z.C., Cortez, D.A.G., and Cortez, L.E.R. (2015). Effects of organic fertilizer in the capsaicinoids of red pepper (Capsicum baccatum L.). Journal of Medicinal Plants Research. 9(29): 787-791.

[27] Ha, SH., Kim, JB., Park, JS., Lee, SW., and Cho, KJ. (2007). A comparison of the carotenoid accumulation in Capsicum varieties that show different ripening colors: Deletion of the capsanthin-capsorubin synthase gene is not a prerequisite for the formation of a yellow pepper. Journal of Experimental Botany. 58(12): 3135-3144.

[28] Howard, L.R., and Wildman, R.E.C. (2007). Antioxidant vitamin and phytochemical content of fresh and processed pepper fruit (Capsicum annuum). In: Wildman REC, editor. Handbook of nutraceuticals and functional foods. 165-191.

[29] Howard, L.R., Talacott, S.T., Brenes, CH., and Villalon, B. (2000). Changes in phytochemical and antioxidant activity of selected peppers cultivars, Journal of Agricultural and Food Chemistry. 48 (1): 713-720.

[30] Jarret, R.L., Baldwin, E., Perkins, B., Bushway, R., and Guthrie, K. (2007). Diversity of fruit quality characteristics in Capsicum frutescens. Horticultural Science. 42: 16-19.

[31] Jeong, W.Y., Jin, J.S., Cho, Y.A., Lee, J.H., Park, S., Jeong, S.W., Kim, Y.H., Lim, C.S., Abd El-Aty, A.M., Kim, G.S., Lee, S.J., Shim, J.H., and Shin, S.C. (2011). Determination of polyphenols in three Capsicum annuum L. (bell pepper) varieties using high-performance liquid chromatography-tandem mass spectrometry: their contribution to overall antioxidant and anticancer activity. Journal of Separation Science. 34(21):2967-2974.

[32] Kappel, V.D., Costa, G.M., Scola, G., Silva, F.A., Landell, M.F., Valente, P., Souza, D.G., Vanz, D.C., Reginatto, F.H., and Moreira, J.C. (2008). Phenolic content and antioxidant and antimicrobial properties of fruits of Capsicum baccatum L. var. pendulum at different maturity stages. Journal of Medicinal Food. 11(2):267-274.

[33] Laskaridou-Monnerville, A. (1999). Determination of capsaicin and dihydrocapsaicin by micellar electrokinetic capillary chromatography and its application to various species of Capsicum, Solanaceae. Journal of Chromatography A, 836: 293-302.

[34] Lee, J.E., Chang, Y.H., Ganesan, P., and Kwak, H.S. (2011). Concentration of n-3 polyunsaturated fatty acids in cholesterol-reduced cod-liver oil by lipases. International Journal of Food Science and Technology. 46: 1462-1468

[35] Lingle, S.E., and Dunlap, J.R. (1987). Sucrose metabolism in netted muskmelon fruit during development. Plant Physiology. 84: 386-389.

[36] Manirakiza, P.A., Covaci, A., and Schepens, P. (2003), Pungency principles. In Capsicum. The genus Capsicum; A.K., Ed., Taylor and Francis: London, UK, pp. 71-86.

[37] Martel, J., Ojcius, D.M., Chang, C.J., Lin, C.S., Lu, C.C., Ko, Y.F., et al. (2017). Anti-obesogenic and antidiabetic effects of plants and mushrooms. Nature Reviews Endocrinology. 13: $149-160$.

[38] Matsufuji, H., Nakamuro, H., Chino, M., and Mitsuharo, T. (1998). Antioxidant activity of capsanthin and the fatty acid esters in paprika (Capsicum annuum). Journal of Agricultural and Food Chemistry. 46: 3462-3472.

[39] Middleton, E.Jr., Kandaswami, C., and Theoharides, TC. (2000). The effects of plant flavonoids on mammalian cells: Implications for inflammation, heart disease, and cancer. Pharmacology Review. 52:67-751.

[40] Mori, A., Lehmann, S., O’Kelly, J., T.Kumagai, et al. (2006). Capsaicin component of red peppers, inhibits the growth of androgen-independent, p53mutant prostate cancer cells .Cancer Res. 66: 3222-3229.

[41] Munns R. (2008). Tester M. Mechanisms of salinity tolerance. Annual Review of Plant Biology. 59: 651-681.

[42] Munns, R. (2002). Comparative physiology of salt and water stress. Plant cell and Environment. 25: 239-250.

[43] Nadeem, M., Faqir, M., Anjum, Moazzam Rafiq Khan, Saeed, M., Asad Riaz. (2011). Antioxidant Potential of Bell Pepper (Capsicum annum L.)-A Review. Pakistan Journal of Food Sciences. 21(1-4): 45-51.

[44] Nei, M. (1973). Analysis of gene diversity in subdivided population, proceeding of the national academy of sciences. USA, 70 (12): 3321-3323.

[45] Nsabiyera, V., Logose, M., Ssemakula, M. O., Sseruwagi, P., Gibson P., and Ojiewo, C. (2013). Morphological Characterization of Local and Exotic Hot Pepper (Capsicum annum L.) Collections in Uganda. Bioremediation, Biodiversity and Bioavailability. 7: 22-32.

[46] Popovsky, S., and Paran, I. (2000). Molecular genetics of the $\mathrm{Y}$ locus in pepper: its relation to capsanthin - capsorubin synthase and fruit color. Theoretical and Applied Genetics. 101: 86-89.

[47] Qin, J., Li, Y., Cai, Z., Li, S., Zhu, J., Zhang, F., et al. (2012). A metagenome-wide association study of gut microbiota in type 2 diabetes. Nature. 490 (7418):55-60. 
[48] Ranjith, A., Natarajan, R.B., Menon, K.R., Chandrasekhar L.P., and Moorkoth, V. (2015). Red pepper (Capsicum annuum) carotenoids as a source of natural food colors: analysis and stability. Journal of Food, Science and Technology. 52(3):1258-1271.

[49] Rodica, S., Dinu, M., Babeanu, C., Popescu, M., Popescu, A. (2017). Nutritional value and antioxidant activities in fruit of some cultivars of pepper (Capsicum annuum L.). Journal of Agroalimentary Processes and Technologies. 23 (4): 217-222.

[50] Rose, D.P., and Connolly, J.M. (1999). Omega-3 fatty acids as cancer chemo-preventive agents. Pharmacology and Therapeutics. 83(3):217-244.

[51] Schulze, B., and Spiteller, D. (2009). Capsaicin: Tailored chemical defense against unwanted "Frugivores". Chem. bio. chem., European Journal of chemical biology. 10 (3): 428-429

[52] Scoville, W.L., (1912). Note on Capsicums. Journal of the American Pharmacists Association. 1: 453-454.

[53] Shannon, C.E., and Weaver, W. (1949). The Mathematical Theory of Communication. University of Illinois. Urbana. Chicago. IL, USA. 3-24.

[54] Sharma, SK., Vij, AS., Sharma, M. (2013). Mechanisms and clinical uses of capsaicin. European Journal of Pharmacology. 720:55-62.

[55] Simonne, A.H., Simonne, E.H., Eitenmiller, R.R., Mills, H.A., and Green, N.R. (1997). Ascorbic acid and provitamin A contents in unusually colored bell peppers (Capsicum annuum L.). Journal of Food Composition. 10: 299-311.

[56] Simopoulos, A.P. (2002). The importance of the ratio of omega-6/omega-3 essential fatty acids. Biomedicine and Pharmacotherapy. 56(8):365-379.

[57] Simopoulos, A.P. (2008). The importance of the Omega-6/Omega-3 fatty acid ratio in cardiovascular disease and other chronic diseases. Experimental Biology and Medicine (Maywood). 233(6): 674-688.

[58] Simopoulos, AP. (2010). Genetic variants in the metabolism of omega- 6 and omega- 3 fatty acids: their role in the determination of nutritional requirements and chronic disease risk. Exp Biol Med. 235(7):785-95.

[59] Slinkard, K., and Singleton, V.L. (1977). Total phenol analyses: automation and comparaison with Manual Methods. American Journal of Enology and viticulture. 28: 49-55.

[60] Stewards, C., Kang, B.C., Liu, K., Mazourek, M., Moore, S.L., Yoo, E.Y., Kim, B.D., Paran I., and Jahn, M.M. (2005). The Pun 1 gene for pungency in pepper en codes a putative acytransferase. Plant Journal. 42: 675-688.

[61] Topuz, A., and Ozdemir, F. (2007). Assessment of carotenoids, capsaicinoids and ascorbic acid composition of some selected pepper cultivars (Capsicum annuum L.) grown in Turkey. Journal of Food Composition and Analysis. 20: 596-602.

[62] Tundis, R., Loizzo, M.R., Menichini, F., Bonesi, M., Conforti, F., Luca, D.D., and Menichini, F. (2012). Air-dried capsicum annuum var. acuminatum medium and big: Determination of bioactive constituents, antioxidant activity and carbohydrate-hydrolyzing enzymes inhibition. Food Research International. 45: 170-175.

[63] Wahyuni, Y., Ballester, A.R., Sudarmonowati, E., Bino R.J., and Bovy, A.G. (2013). Secondary metabolites of Capsicum species and their importance in the human diet. Journal of Natural Products. 76 (4): 783-793.

[64] Weiss, E.A. (2002). Spice Crops. CABI Publishing International. New York, USA. 411p.

[65] Yemm, E.W., and Willis, A.J. (1954). The Estimation of Carbohydrates in Plant Extracts by Anthrone. Biochemical Journal. 57(3): 508-514.

[66] Zaki, N., Hasib, A., Hakmaoui, A., Dehbi, F., and Aaziz, O. (2013). Assessment of color, capsaicinoids, carotenoids and fatty acids composition of paprika produced from Moroccan pepper cultivars (Capsicum annuum L.). Journal of Natural Sciences Research. 3(7):110-119.

[67] Zewdie, Y. and Bosland, P.W. (2000). Evaluation of genotype, environment and genotype-by environment interaction for capsaicinoids in Capsicum annuum $\mathrm{L}$. Euphytica. 111:185-190

[68] Zhani, K., Hermans, N., Ahmad, R., and Hannachi, Ch. (2013). Evaluation of Salt Tolerance $(\mathrm{NaCl})$ in Tunisian Chili Pepper (Capsicum frutescens L.) on Growth, Mineral Analysis and Solutes Synthesis. Journal of stress physiology and biochemistry. 9(1): 209-228.

[69] Zhu, J. K. (2002). Salt and drought stress signal transduction in plants. Annual Review of Plant Biology. 53: 247-273.

[70] Zimmer, A.R., Leonardi, B., Miron, D., Schapoval, E., Oliveira, J.R.D., and Gosmann, G. (2012). Antioxidant and anti-inflammatory properties of capsicum baccatum: from traditional use to scientific approach. Journal of Ethnopharmacology. 139 (1): 228-233. 